\title{
Role of Voltage-Gated Sodium Channels in the Mechanism of Ether-Induced Unconsciousness
}

\author{
Nicholas Denomme, Jacob M. Hull, and George A. Mashour \\ Departments of Pharmacology (N.D.) and Anesthesiology (G.A.M.), Center for Consciousness Science (N.D., G.A.M.), and Neuroscience \\ Graduate Program (J.M.H., G.A.M.), University of Michigan, Ann Arbor, Michigan
}

Abstract ......................................................... 450

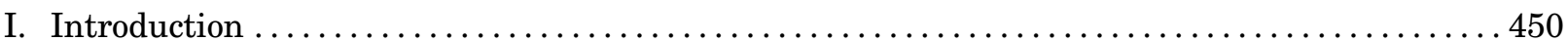

A. Scope and Relevance ............................................... 450

B. Historical Background and Clinical Use of the Halogenated Ethers................. 451

II. Basic Pharmacology and Physicochemical Properties of the Halogenated Ethers........... 452

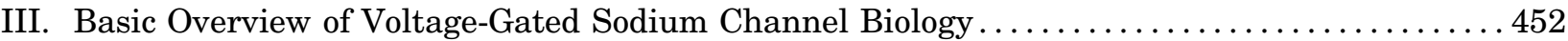

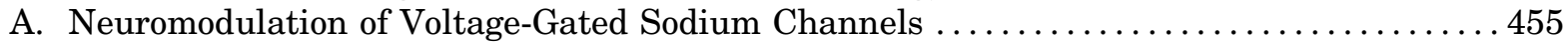

IV. Molecular Interactions of Halogenated Ethers with Voltage-Gated Sodium Channels ....... 456

V. Structural and Computational Studies Using Prokaryotic Voltage-Gated Sodium

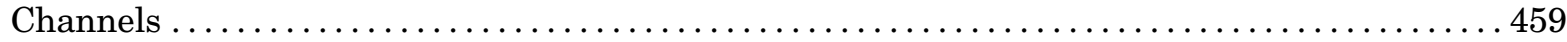

VI. Presynaptic Voltage-Gated Sodium Channel Inhibition Leads to Depressed

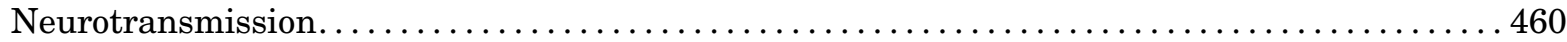

VII. In Vivo Modulation of Halogenated Ether Anesthesia .......................... 461

A. Modulation of Anesthetic Sensitivity Mediated by Pharmacological Manipulation of

Voltage-Gated Sodium Channels..................................... 461

1. Overlap with Local Anesthetic Mechanism of Action ........................ 461

B. Modulation of Anesthetic Sensitivity Mediated by Genetic Manipulation of Voltage-

Gated Sodium Channels.................................................... 462

VIII. Conclusion........................................................ 463

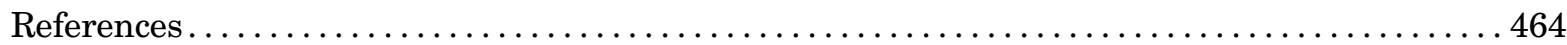

Abstract_-Despite continuous clinical use for more than 170 years, the mechanism of general anesthetics has not been completely characterized. In this review, we focus on the role of voltage-gated sodium channels in the sedative-hypnotic actions of halogenated ethers, describing the history of anesthetic mechanisms research, the basic neurobiology and pharmacology of voltage-gated sodium channels, and the evidence for a mechanistic interaction between halogenated ethers and sodium channels in the induction of unconsciousness. We conclude with a more integrative perspective of how voltage-gated sodium channels might provide a critical link between molecular actions of the halogenated ethers and the more distributed network-level effects associated with the anesthetized state across species.

\section{Introduction}

\section{A. Scope and Relevance}

Despite more than 170 years of clinical use and scientific study, the molecular mechanism of action of ether anesthesia remains incompletely understood. Characterizing the molecular events by which anesthetic agents lead to the loss of consciousness is important for both clinical and basic science. From a clinical perspective, there are more than 300 million major surgeries around the world each year, which typically occur under general anesthesia (Weiser et al., 2015). Understanding the structure-activity relationships of anesthetic action can potentially lead to the development of safer and more efficacious anesthetic drugs. In addition to the practical applications, elucidating the molecular mechanisms of

Address correspondence to: Dr. George A. Mashour, Department of Anesthesiology, Center for Consciousness Science, University of Michigan Medical School, 1500 E. Medical Center Drive, 1H247 University Hospital, SPC-5048, Ann Arbor, MI, 48109-5048. E-mail: gmashour@umich.edu

https://doi.org/10.1124/pr.118.016592. 
anesthetic-induced unconsciousness has implications for pharmacology as well as the neurobiology of consciousness itself.

The clinical state of general anesthesia is characterized by the pharmacological induction of amnesia, unconsciousness, analgesia, and immobility. General anesthesia is reversible and can be induced by a structurally diverse range of molecules administered either intravenously or by inhalation. A large body of evidence now supports inhaled anesthetics acting on diverse anatomic sites and molecular targets within the nervous system to produce the array of clinical endpoints seen during general anesthesia. This review will focus on the class of inhaled anesthetics known as the halogenated ethers and the role that voltage-gated sodium channels (VGSCs) play in their mechanism of sedative-hypnotic action.

\section{B. Historical Background and Clinical Use of the Halogenated Ethers}

In 1540, German botanist and physician Valerius Cordus heated a mixture of triply-distilled wine (ethanol) with vitriol (sulfuric acid) (Cordus, 1561). Cordus named the sweet-smelling remains "oleum dulci vitrioli," which is Latin for the sweet oil of vitriol. Cordus's sweet oil was diethyl ether, commonly referred to as ether.

For the following three centuries after Cordus's initial discovery, ether was primarily used recreationally. Although not made public, Dr. Crawford Long performed surgeries under ether at his private practice in Jefferson, Georgia, from 1842 to 1846 . He did not publish his findings until 1849 (Long, 1849). The widespread use of ether as a general anesthetic was ushered in on October 16, 1846 in the first successful public demonstration of surgery under diethyl ether anesthesia by dentist William T. G. Morton (Bigelow, 1846). Morton's new "miracle" gas Letheon enabled renowned American surgeon John Collins Warren to remove a neck tumor from a patient without any pain or knowledge of the operation at a time when, without such interventions, surgical patients could be completely conscious of these major traumatic interventions (Fenster, 2001).

Subsequently, diethyl ether was used to achieve general anesthesia for over 75 years. Ether had many shortcomings, notably its flammable and explosive properties. The dangerous properties of diethyl ether arise from a combination of factors, including its low boiling point, high vapor pressure, and tendency to form explosive peroxides. The necessity for a safer and nonflammable alternative led to a wealth of research into general anesthetics in the first half of the 20th century.
As halogen chemistry developed, it was found that a halogenated derivative would greatly reduce the flammability of diethyl ether. In the 1930s, chemists Harold Booth and E. Max Bixby were the first to try synthesizing a fluorinated anesthetic. Although they failed with their compound monochlorodifluoromethane, Booth and Bixby (1932) recognized the importance of fluorine substitutions in developing a noncombustible volatile anesthetic. Thorough analysis of organic fluoride-based compounds led them to the observation that fluorination would improve molecular stability and toxicity.

Earl McBee directed a Manhattan Project initiative to refine ${ }^{235} \mathrm{U}$ by first converting it to the uranium hexafluoride intermediate. His expertise in fluorination ultimately resulted in a grant from Mallinckrodt Chemical Works to produce new fluorinated hydrocarbons as potential anesthetics (Whalen et al., 2005). The McBee group synthesized dozens of compounds, none of which displayed anesthetic properties. Vanderbilt Pharmacologist Ben Robbins tested the fluorinated hydrocarbons. Although none succeeded, his analysis was optimistic, and he encouraged further exploration in the area (Robbins, 1946).

A University of Maryland pharmacology group led by John Krantz published dozens of articles in The Journal of Pharmacology \& Experimental Therapeutics, and Anesthesiology from 1940 to 1961, investigating the properties of hundreds of ethers and hydrocarbons (Calverley, 1986). The 40th study in their series reported the effects of trifluoroethyl vinyl ether (Krantz et al., 1953). In 1954, the Ohio Chemical and Surgical Company introduced trifluoroethyl vinyl ether (fluroxene) into clinical use as the first halogenated ether for general anesthesia (Calverley, 1986). Although much safer than ether, fluroxene was potentially flammable at supraclinical concentrations. Additionally, it caused severe nausea and vomiting. In 1974, after 20 years on the market, fluroxene was withdrawn. This came shortly after it was discovered that fluroxene was metabolized into multiple toxic metabolites, including trifluoroethanol (Cascorbi and Singh-Amaranath, 1972). Methoxyflurane was introduced in 1960, sustaining popularity for a decade (Artusio et al., 1960). Its high lipid solubility caused long postoperative recovery times. Reports of methoxyflurane causing dose-related nephrotoxicity due to inorganic fluoride began to emerge (Crandell et al., 1966). It too was withdrawn from the market. Throughout the 1960s and 1970s, the chemistry group led by Ross Terrell synthesized hundreds of fluorinated compounds that were screened for anesthetic

ABBREVIATIONS: 4-AP, 4-aminopyridine; LA, local anesthetic; MAC, minimum alveolar concentration; PKA, protein kinase A; PKC, protein kinase C; PV, parvalbumin; TTX, tetrodotoxin; $\mathrm{V}_{1 / 2}$, half-maximal voltage; VGSC, voltage-gated sodium channel; $\mathrm{V}_{\mathrm{h}}$, holding potential of the membrane in $\mathrm{mV}$. 
activity (Terrell, 2008). Four of those compounds (enflurane, isoflurane, desflurane, and sevoflurane) eventually were introduced into clinical care.

Due to its tendency to be cardiotoxic and proconvulsant, enflurane was never used widely in the clinical setting. Although isoflurane was synthesized in 1965, 2 years after its structural isomer enflurane, it was not introduced into general clinical practice in the United States until 1981. Technical difficulties in purifying the molecule delayed testing in animals, a problem ultimately resolved by Louise Speers. Delayed use came from concerns over the potential carcinogenic effects of isoflurane anesthesia. These fears motivated intense safety screening in animals during the 1970s. Due to the elevated scrutiny, isoflurane is widely considered the most thoroughly studied halogenated ether.

Desflurane and sevoflurane are the two most recently approved halogenated ethers (Young and Apfelbaum, 1995). With lower blood-gas solubility than their predecessors, desflurane and sevoflurane provide the anesthesiologist with nimbler titratability. The pharmacokinetic properties of desflurane and sevoflurane cause faster anesthetic induction and allow the patient to regain consciousness more rapidly upon emergence (Tempelhoff, 1997). In addition, desflurane and sevoflurane largely resist metabolism in vivo (Lavelle and Kurra, 2017). This lack of biotransformation contributes to the high safety profile of the two agents.

\section{Basic Pharmacology and Physicochemical Properties of the Halogenated Ethers}

Despite the long clinical history and extensive characterization of the properties of halogenated ethers (see Fig. 1; Table 1), their precise molecular mechanisms of action remain unclear. Evidence points to pre- and postsynaptic ligand-gated ion channels and voltagegated ion channels as highly relevant targets of halogenated ether-induced unconsciousness (Campagna et al., 2003; Covarrubias et al., 2015). Broadly speaking, general anesthetics act via depression of excitatory signaling and/or enhancement of inhibitory signaling. Under this generalization, many known protein targets exist. $\mathrm{GABA}_{\mathrm{A}}$, glycine, glutamate, nicotinic acetylcholine, and $5-\mathrm{HT}_{3}$ receptors, among others, have been implicated (Mashour et al., 2005; Forman and Chin, 2008). For further discussion of the promiscuous molecular pharmacology of general anesthetics, see the comprehensive reviews (Franks and Lieb, 1994; Campagna et al., 2003; Rudolph and Antkowiak, 2004; Hemmings et al., 2005b; Franks, 2006, 2008). In addition to neurotransmitter receptors, a growing body of evidence has emerged indicating VGSCs as mediators of some of the effects of halogenated ethers (Hemmings, 2009; Herold and Hemmings, 2012).

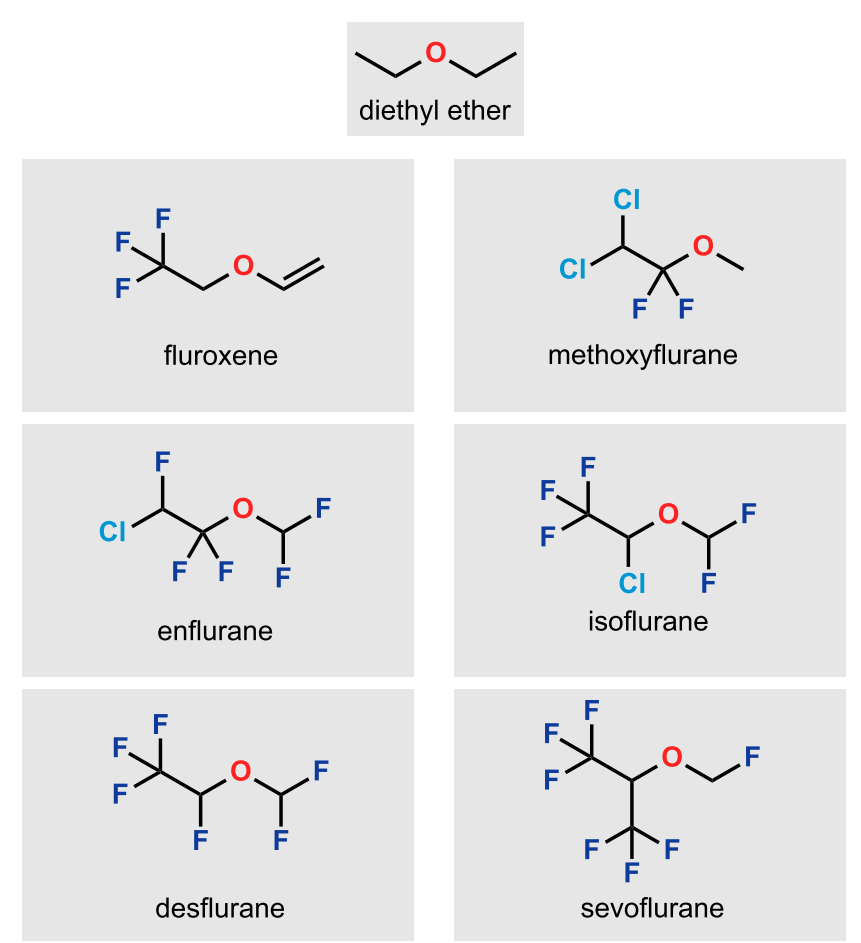

Fig. 1. Molecular structures of diethyl ether and the halogenated ethers.

\section{Basic Overview of Voltage-Gated Sodium Channel Biology}

VGSCs are transmembrane protein complexes responsible for the initiation and propagation of action potentials in neurons as well as most excitable cells (Hille, 2001). VGSCs consist of a pore-forming $\alpha$-subunit $(220-260 \mathrm{kDa})$ and smaller nonpore-forming $\beta$-subunits, $30-40 \mathrm{kDa}$ in size (Beneski and Catterall, 1980). VGSC $\alpha$-subunits alone are sufficient for ion conduction and voltage sensing, whereas $\beta$-subunits play many roles, including the modification of channel expression, gating, localization, as well as functioning as a cell adhesion and signaling molecule (Goldin et al., 1986; Hull and Isom, 2018). VGSCs transition between several conformations through the course of an action potential, including closed, open, and inactivated states (see Fig. 2). The predominant state of the channel at resting membrane potential is the closed state, where no $\mathrm{Na}^{+}$ ions are conducted. Upon sufficient membrane depolarization, channels undergo a conformational change to the open state, where $\mathrm{Na}^{+}$ions enter the cell and drive further depolarization. After transition to the open state, fast inactivation is enhanced, in which intracellular residues (the inactivation gate) occlude the inside face of the channel, blocking further conduction. Such fast inactivation (recovery time constants on the scale of milliseconds) is distinct from slow inactivation (recovery time constants on the scale of hundreds of milliseconds to seconds), which is discussed in more detail below. The comparatively slower rate of inactivation to 
TABLE 1

Basic physicochemical properties of the halogenated ethers

\begin{tabular}{|c|c|c|c|c|c|c|c|}
\hline $\begin{array}{l}\text { Halogenated } \\
\text { Ether }\end{array}$ & $\begin{array}{c}\text { Clinical } \\
\text { Introduction (US) }\end{array}$ & $\underset{\left({ }^{\circ} \mathrm{C}\right)}{\text { Boiling Point }}$ & $\begin{array}{l}\text { Vapor Pressure } \\
\left(\mathrm{mmHg} 20^{\circ} \mathrm{C}\right)\end{array}$ & $\begin{array}{l}\text { MAC \% (Age } \\
30-55,1 \text { atm) }\end{array}$ & $\begin{array}{c}\text { Blood/Gas Partition } \\
\text { Coefficient }\left(37^{\circ} \mathrm{C}\right)\end{array}$ & $\begin{array}{l}\text { Oil/Gas Partition } \\
\text { Coefficient }\left(37^{\circ} \mathrm{C}\right)\end{array}$ & $\begin{array}{l}\mathrm{EC}_{50} \\
(\mathrm{mM})\end{array}$ \\
\hline Fluroxene & 1954 & 43.2 & 286 & 3.4 & 1.37 & 47.7 & - \\
\hline Methoxyflurane & 1960 & 105 & 22.5 & 0.2 & 12 & 950 & $0.27^{a}$ \\
\hline Enflurane & 1972 & 57 & 172 & 1.63 & 1.9 & 99 & $0.49^{b}$ \\
\hline Isoflurane & 1981 & 48 & 240 & 1.17 & 1.4 & 90.8 & $0.27^{b}$ \\
\hline Desflurane & 1992 & 23 & 669 & 6 & 0.45 & 19 & $0.53^{b}$ \\
\hline Sevoflurane & 1995 & 59 & 170 & 2 & 0.65 & $47-54$ & $0.30^{b}$ \\
\hline
\end{tabular}

Values for fluroxene obtained from Morris (1972). All other physicochemical property values obtained from Miller et al. (2015) or Lavelle and Kurra (2017). EC 50 values in human obtained from ${ }^{a}$ Franks and Lieb (1993), ${ }^{b}$ Franks and Lieb (1996). atm, atmosphere.

activation and deactivation allows for timely termination of depolarization during an action potential and supports the refractory period between action potentials (Hille, 2001). Entry into the slow inactivated state requires repetitive or sustained depolarizations that accumulate channels in the slow inactivated state over the course of numerous action potentials (Schauf et al., 1976). Recovery from the slow inactivated state is much slower than entry, supporting longer-lasting effects on the channel than fast inactivation, which is limited to affecting fewer individual action potentials due to its fast recovery time constant. VGSC slow inactivation has the interesting property that at the depolarized potentials that support spiking (i.e., $-70 \mathrm{mV}$ ), the recovery from slow inactivation is slow, whereas at hyperpolarized potentials (i.e., $-80 \mathrm{mV}$ ), the recovery is much faster (Fleidervish et al., 1996; Jung et al., 1997). This

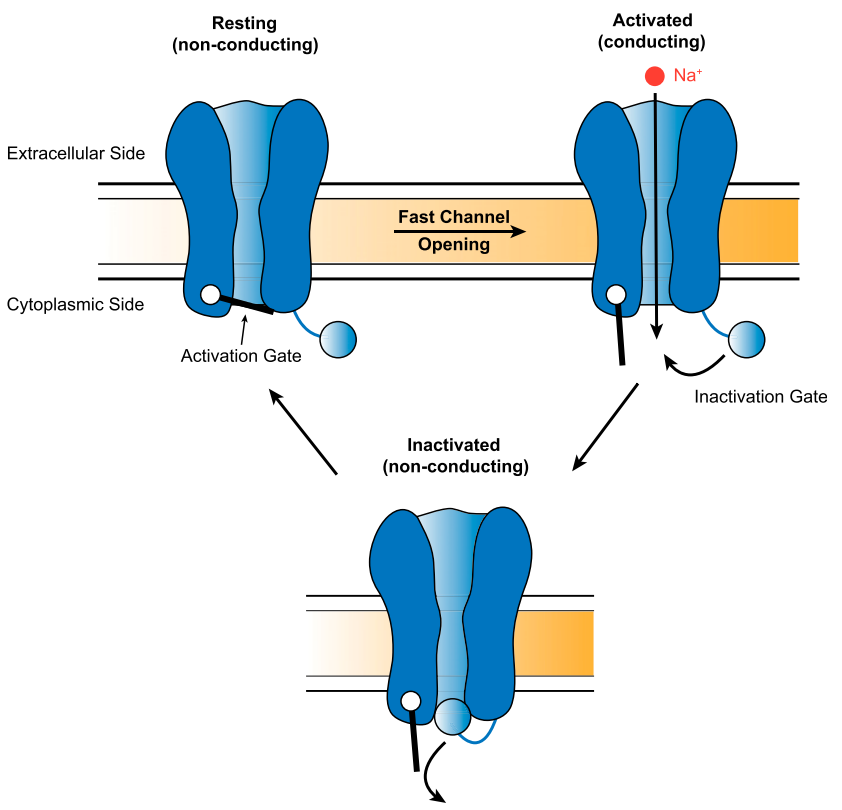

Fig. 2. Transition states of voltage-gated sodium channels. At rest, the activation gate is closed and the channel is in a nonconducting state. After sufficient depolarization of the membrane, the channel undergoes a conformational change to enter the activated state where both gates are open, allowing the conduction of $\mathrm{Na}^{+}$ions. After transitioning to the activated state, the channel undergoes fast inactivation, where intracellular residues (the inactivation gate) occlude the inside face of the channel blocking further conduction of $\mathrm{Na}^{+}$ions. After recovery from inactivation, the channel returns to the resting state. voltage-dependent effect is highly relevant to neuromodulation, as discussed below.

The different conformational states rely on the activity of distinct regions of the channel, indicating that distinct channel states and their role in general anesthesia can be tested pharmacologically. VGSC $\alpha$-subunits consist of four homologous domains, each composed of six transmembrane segments (see Fig. 3). Segments 1-4 (S1-S4) are primarily involved in voltage sensing, whereas S5-S6 form the pore. Positively charged lysine and arginine residues in the $\mathrm{S} 4$ helices act as voltage sensors. A short loop on the intracellular side of the channel linking domains III and IV forms the inactivation gate. Slow inactivation utilizes molecular mechanisms that differ from fast inactivation. Mutations that impair fast inactivation do not prevent slow inactivation (Rudy, 1978; Featherstone et al., 1996; Vedantham and Cannon, 1998; Todt et al., 1999; Mitrovic et al., 2000; Ong et al., 2000). Although numerous mutations in VGSCs have been found to affect slow inactivation, the S6 segments contain highly conserved asparagine residues that, when mutated to hydrophobic residues, completely block slow inactivation (Carr et al., 2003; Chen et al., 2006).

Ten different human VGSC $\alpha$-subunit isoforms $\left(\mathrm{Na}_{\mathrm{v}} 1.1-1.9+\mathrm{Na}_{\mathrm{x}}\right)$ encoded by the $\operatorname{SCN}(X) A$ genes have been characterized (see Table 2). VGSC $\alpha$-subunits can be divided into two classes based on their sensitivity to tetrodotoxin (TTX). $\mathrm{Na}_{\mathrm{v}} 1.1-1.4, \mathrm{Na}_{\mathrm{v}} 1.6$, and $\mathrm{Na}_{\mathrm{v}} 1.7$ are TTX-sensitive, as half-maximal block of $\mathrm{Na}^{+}$conduction by TTX occurs at concentrations between 1 and $25 \mathrm{nM}$ (Catterall et al., 2005). $\mathrm{Na}_{\mathrm{v}} 1.5, \mathrm{Na}_{\mathrm{v}} 1.8$, and $\mathrm{Na}_{\mathrm{v}} 1.9$ are referred to as TTX-resistant, requiring $>1 \mu \mathrm{M}$ TTX for block of half-maximal conduction. All of the human VGSC subtypes share greater than $75 \%$ amino acid sequence identity (Catterall et al., $2005)$. When VGSC $\alpha$-subunits were originally purified from rat brain, it was discovered that $\beta$-subunits were present in a heterotrimeric complex (Beneski and Catterall, 1980). Five $\beta$-subunit isoforms have been discovered (O'Malley and Isom, 2015). Heterologous expression of VGSC $\alpha$-subunits alone is sufficient for functional $\mathrm{Na}^{+}$conduction, but the presence of $\beta 1$ or $\beta 3$ and $\beta 2$ or $\beta 4$ confers further modularity to channel function and expression. $\beta 1$ or $\beta 3$ associates noncovalently, and $\beta 2$ or $\beta 4$ forms disulfide bonds with 


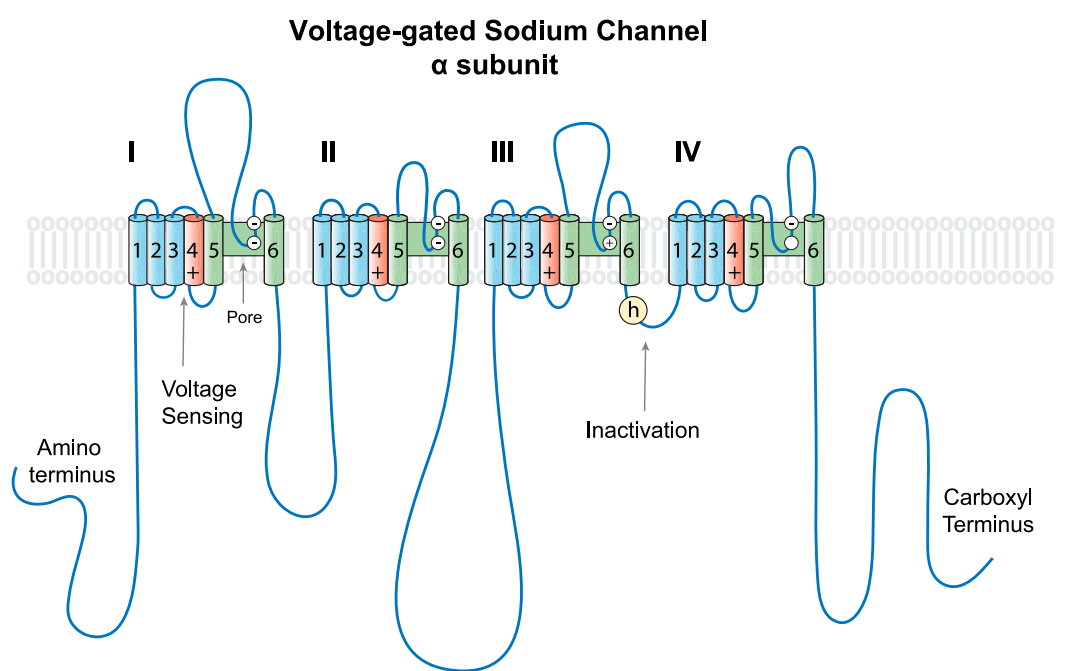

Fig. 3. Schematic of the eukaryotic VGSC $\alpha$-subunit. Roman numerals and numbers indicate domains and segments, respectively. The pore loop regions comprised of segments S5 and S6 are highlighted in green. Voltage-sensing S4 segments are highlighted in red. The inactivation gate and "h" particle containing the IFMT motif that is crucial for inactivation are highlighted in yellow. Small white circles of the re-entrant loops in each domain represent the amino acid residues that form the $\mathrm{Na}^{+}$ion selectivity filter.

$\alpha$-subunits. In addition to modulation of channel expression and function, $\beta$-subunits act as cell adhesion molecules, with roles in cellular aggregation, neurite extension, and axonal fasciculation (Hull and Isom, 2018). Each VGSC subtype is uniquely distributed within and across cell and tissue types, indicating that specific regional- or cell type-selective mechanisms of general anesthesia may be investigated through manipulation of specific VGSCs. Each subtype has distinctive kinetic and voltage-sensing properties. VGSC subtypes are strategically expressed based on these properties to maximize physiologic function. $\mathrm{Na}_{\mathrm{v}} 1.1-1.3$ and $\mathrm{Na}_{\mathrm{v}} 1.6$ are the most prominent central nervous system VGSCs, whereas the $\mathrm{Na}_{\mathrm{v}} 1.7-1.9$ isoforms are mainly expressed in the peripheral nervous system. $\mathrm{Na}_{\mathrm{v}} 1.4$ and $\mathrm{Na}_{\mathrm{v}} 1.5$ are mainly expressed in skeletal and cardiac muscle, respectively (Catterall et al., 2005). The different VGSCs expressed in brain exhibit isoform enrichment in a cell type- and subcellular regiondirected manner. In this study, we focus on VGSC $\alpha$-subunits; for a review of $\beta$-subunit expression patterns, see Hull and Isom (2018). In the adult brain, $\mathrm{Na}_{\mathrm{v}} 1.1, \mathrm{Na}_{\mathrm{v}} 1.2$, and $\mathrm{Na}_{\mathrm{v}} 1.6$ are the predominant VGSCs, whereas $\mathrm{Na}_{\mathrm{v}} 1.3$ is highly expressed in the soma of neurons during development, but shows low expression in the adult brain (Yu and Catterall, 2003). In the forebrain, $\mathrm{Na}_{\mathrm{v}} 1.1 \mathrm{mRNA}$ and protein are highly expressed in GABAergic inhibitory interneurons, although weaker expression exists in pyramidal neurons of the cortex and hippocampus (Westenbroek et al., 1989; Gong et al., 1999; Van Wart et al., 2007; Okaty et al., 2009). In interneurons, subcellular localization of $\mathrm{Na}_{\mathrm{v}} 1.1$ protein is enriched in the cell body and to a greater degree in the axon initial segment (Ogiwara et al., 2007). $\mathrm{Na}_{\mathrm{v}} 1.2$ expression is enriched in the axons of somatostatin- but not parvalbumin (PV)-positive interneurons of the cortex, showing further cellular subtype enrichment in VGSC expression ( $\mathrm{Li}$ et al., 2014). $\mathrm{Na}_{\mathrm{v}} 1.2$ is also expressed highly in the proximal axon initial segment of pyramidal neurons and, during development, highly at nodes of Ranvier. $\mathrm{Na}_{\mathrm{v}} 1.2$ expression is present, but weaker in the cell body and dendrites of pyramidal neurons (Hu et al., 2009). $\mathrm{Na}_{\mathrm{v}}$ 1.6 protein is highly expressed in the axons of PVpositive neurons and in the distal axon initial segment of pyramidal neurons and in nodes of Ranvier (Hu et al., 2009; Li et al., 2014). $\mathrm{Na}_{\mathrm{v}} 1.6$ is also expressed in the cell body and dendrites of pyramidal neurons (Caldwell

TABLE 2

Human VGSC $\alpha$-subunits

\begin{tabular}{llcll}
\hline Gene & $\alpha-$ Subunit & Human Chromosomal Location & \multicolumn{1}{c}{ Primary Tissue Expression } & Tetrodotoxin Sensitivity \\
\hline SCN1A & $\mathrm{Na}_{\mathrm{v}} 1.1$ & $2 \mathrm{q} 24$ & Neurons of the central nervous system & TTX-sensitive \\
SCN2A & $\mathrm{Na}_{\mathrm{v}} 1.2$ & $2 \mathrm{q} 23-24$ & Neurons of the central nervous system & TTX-sensitive \\
SCN3A & $\mathrm{Na}_{\mathrm{v}} 1.3$ & $2 \mathrm{q} 24$ & Neurons of the central nervous system & TTX-sensitive \\
SCN4A & $\mathrm{Na}_{\mathrm{v}} 1.4$ & $17 \mathrm{q} 23-25$ & Skeletal muscle & TTX-sensitive \\
SCN5A & $\mathrm{Na}_{\mathrm{v}} 1.5$ & $3 \mathrm{p} 21$ & Cardiac, denervated skeletal muscle & TTX-resistant \\
SCN8A & $\mathrm{Na}_{\mathrm{v}} 1.6$ & $12 \mathrm{q} 13$ & Neurons of the central nervous system & TTX-sensitive \\
SCN9A & $\mathrm{Na}_{\mathrm{v}} 1.7$ & $2 \mathrm{q} 24$ & Neurons of the peripheral nervous system & TTX-sensitive \\
SCN10A & $\mathrm{Na}_{\mathrm{v}} 1.8$ & $3 \mathrm{p} 22-24$ & Neurons of the dorsal root ganglia & TTX-resistant \\
SCN11A & $\mathrm{Na}_{\mathrm{v}} 1.9$ & $3 \mathrm{p} 21-24$ & Neurons of the dorsal root ganglia & TTX-resistant \\
SCN6/7A & $\mathrm{Na}$ & $2 \mathrm{q} 21-23$ & Uterus, astrocytes, hypothalamus & N/A \\
\hline
\end{tabular}


et al., 2000; Krzemien et al., 2000; Lorincz and Nusser, 2010). The three major adult central nervous system VGSCs show both pre- and postsynaptic localization at synaptic terminals in the hippocampus (Johnson et al., 2017). Such localization appears to be regional/cell class specific, with the central hilus of the dentate gyrus showing predominantly presynaptic $\mathrm{Na}_{\mathrm{v}} 1.1$ immunoreactivity, whereas in the stratum radiatum of CA1, $\mathrm{Na}_{\mathrm{v}} 1.1,1.2$, and 1.6 exhibit stronger postsynaptic localization in spines and dendrites (Johnson et al., 2017). Although most of the work studying the cell typeand subregional-specific VGSC expression and function has focused on cortex and hippocampus, investigation has expanded to thalamic and subthalamic regions of the brain. Recently, it was found that targeted deletion of $S c n 8 a$ (encoding $\mathrm{Na}_{\mathrm{v}} 1.6$ ) in PV-positive neurons of the thalamic reticular nucleus of the thalamus was sufficient to generate absence epilepsy, a nonconvulsive seizure type that is characterized by sudden impairment of consciousness (Makinson et al., 2017). $\mathrm{Na}_{\mathrm{v}} 1.1$ is also expressed in the thalamus, with deletion of Scn1a impacting function of thalamic reticular neurons (Kalume et al., 2015). The role of VGSCs in the mechanism(s) of the impairment of consciousness in absence epilepsy may further elucidate our understanding of the role of VGSCs in the molecular mechanism of halogenated ether-induced unconsciousness. Although the study of VGSCs in the consciousness promoting subcortical regions including the brainstem is nascent, cell type and regional effects of specific VGSCs in these regions are also likely to be highly relevant to mechanisms of general anesthesia.

To date, the successful crystallization of a human VGSC has yet to be accomplished. However, in 2018, the structure of human $\mathrm{Na}_{\mathrm{v}} 1.4$ coexpressed with the $\beta 1$ subunit was resolved at a $3.2-\AA$ resolution using cryogenic electron microscopy (Pan et al., 2018). This marks the highest-resolution structure of a eukaryotic VGSC currently available and may guide pharmacological investigation of VGSCs, including the action of the halogenated ethers. Selectivity of $\mathrm{Na}^{+}$over other ions is an essential function for the action of VGSCs. This is achieved by the precise architecture of a VGSC region known as the selectivity filter. Approximately $4.6 \AA$ in size, the selectivity filter is composed of an inner and outer ring of charged residues. The asymmetric charge distribution of each ring coordinates the solvated $\mathrm{Na}^{+}$ ions as they flow through the pore (Catterall, 2012). Through mutagenesis and subsequent electrophysiological analysis, four key residues (D: aspartate, E: glutamate, K: lysine, and A: alanine), each present in one of the domains, were identified as the inner ring of the mammalian VGSC selectivity filter (Lipkind and Fozzard, 2008). The DEKA motif found in human VGSCs is conserved across all isoforms. Mutating the KA (lysine and alanine) of the DEKA motif to glutamate (EE) abolishes $\mathrm{Na}^{+}$selectivity of the channel and allows
$\mathrm{Ca}^{2+}$ ions to pass through the pore (Heinemann et al., 1992).

\section{A. Neuromodulation of Voltage-Gated Sodium Channels}

VGSCs are affected by the action of various neuromodulators, including acetylcholine, monoamines, neuropeptides, and glutamate (Cantrell and Catterall, 2001). Such modulation by neurotransmitters that are involved in the induction or maintenance of consciousness may represent targets for the pharmacological disruption of consciousness. Administration of the cholinergic agonist carbachol reduces peak $\mathrm{Na}^{+}$current and slows fast inactivation in dissociated hippocampal neurons (Cantrell et al., 1996). This modulation was shown to act via a protein kinase C (PKC)-dependent phosphorylation of VGSCs with similar effects in cortical pyramidal neurons. Cholinergic input to the hippocampus suppresses bursting activity and promotes tonic firing (Azouz et al., 1994; Alroy et al., 1999). The nucleus basalis, a major driver of cholinergic tone in the cortex, shifts cortical spiking from bursting to tonic firing, potentially utilizing modulation of VGSCs, as described above (Metherate et al., 1992). Dopaminergic modulation of VGSCs is also observed. Activation of D1-like dopamine receptors, which stimulate adenylyl cyclase activity, decreases $\mathrm{Na}^{+}$current in acutely isolated hippocampal neurons (Cantrell et al., 1997, 1999). This modulation was shown to be protein kinase A (PKA) dependent. Alternatively, activation of D2 receptors, which are coupled to inhibition of adenylyl cyclase, increases $\mathrm{Na}^{+}$current in medium spiny neurons, but has an overall inhibitory effect through activation of a PKC-mediated pathway. Both PKA and PKC phosphorylate VGSCs to mediate a reduction in $\mathrm{Na}^{+}$ current. Effects on $\mathrm{Na}^{+}$current are limited to depolarized potentials, with similar features to slow inactivation, as described above, leading to the proposal that PKC and PKA modulation acted on the slow inactivation process (Carr et al., 2003). Indeed, it was found that mutation of an asparagine in S6 required for slow inactivation to alanine increased slow inactivation and potentiated the effects of PKC and PKA modulation, whereas mutation to aspartate blocked slow inactivation and prevented modulation by PKA and PKC. Modulation of VGSCs by PKA and PKC exhibits synergistic modulation (Li et al., 1993; Scheuer, 2011). Those residues that are phosphorylated by PKC, but not PKA, when mutated to block phosphorylation, also blocked the reduction in $\mathrm{Na}^{+}$current by PKA activation. In the absence of PKC modulation, PKA requires membrane depolarization for effective modulation, whereas, in the presence of PKC modulation, PKA modulation occurs at all potentials (Cantrell et al., 1996). This interface between neuromodulation and activity dependence provides a rich environment for mechanisms of action for general anesthetics in the 
disruption of consciousness, which is likely to depend on both neuronal activity patterns and neuromodulatory tone in the brain.

It is important to note the effects of phosphorylation on VGSC activity are specific to the cellular environment in which they are studied. Careful attention is required to understand the influence that an experimental expression system may have on the resulting VGSC modulation observed. Not surprisingly, given the high degree of differential expression of the VGSCs in cell type and subcellular domains, the different VGSC $\alpha$-subunits also exhibit differential sensitivity to neuromodulation by PKA and PKC. $\mathrm{Na}_{\mathrm{v}} 1.6$ is far less sensitive to PKA and PKC modulation than $\mathrm{Na}_{\mathrm{v}} 1.2$ (Maurice et al., 2001; Chen et al., 2008). Recent work has found that activation of $5-\mathrm{HT}_{1 \mathrm{~A}}$ receptors in prefrontal cortical layer 5 pyramidal neurons differentially decreases $\mathrm{Na}^{+}$current in the proximal axon attributable to $\mathrm{Na}_{\mathrm{v}} 1.2$ while not impacting those in the distal axon, attributable to $\mathrm{Na}_{\mathrm{v}} 1.6$ showing subcompartmentspecific action of neuromodulators on VGSC function. As described above for PKA and PKC modulation, the effect of $5-\mathrm{HT}_{1 \mathrm{~A}}$ receptor activation on reducing $\mathrm{Na}^{+}$ current could be attributed to enhancing slow inactivation and depolarizing the voltage dependence of channel activation (Yin et al., 2017). The importance of neuromodulation in regulating VGSC availability may provide insights into how the disruption or potentiation of such effects is involved in the mechanism of action of halogenated ethers in the disruption of consciousness.

\section{Molecular Interactions of Halogenated Ethers with Voltage-Gated Sodium Channels}

In 1940, Heinbecker and Bartley reported a marked increase in the rate of accommodation to subthreshold depolarizations seen in the presence of $24 \mathrm{mM}$ ether. It is now known that the accommodation rate is directly proportional to the rate of $\mathrm{K}^{+}$channel activation and $\mathrm{Na}^{+}$channel inactivation. Due to the low potassium conductance in frog nerve, this may have been the first electrophysiological indication of ether's action on sodium channel function (Heinbecker and Bartley, 1940). In 1956, Stephen Thesleff examined the effect of numerous nonvolatile anesthetics on the action potential of frog skeletal muscle using what was, at the time, the new voltage-clamp technique (Thesleff, 1956). All agents tested increased firing threshold and reduced action potential amplitude, mostly at concentrations higher than those relevant to clinical anesthesia. At the time, the idea that voltage-controlled channels in the membrane were carrying $\mathrm{Na}^{+}$ions was hypothetical. Thesleff (1956) was aware of the ionic hypothesis underlying the action potential proposed during his time (Hodgkin and Katz, 1949; Hodgkin and Huxley, 1952). Decades before the molecular characterization of VGSCs, he hypothesized that the reduction in excitability caused by anesthetic agents could be due to a reduction in the selective $\mathrm{Na}^{+}$conductance across the membrane. He attributed the anesthetic reduction in action potential amplitude to what he called an "inhibition of the sodium carrying mechanism" (Thesleff, 1956).

The same sodium-dependent action potential blockade was also seen in isolated frog skeletal muscle fiber with diethyl ether and chloroform (Yamaguchi, 1961; Inoue and Frank, 1965). Combined with their finding that the local anesthetic (LA) procaine also blocked action potential conduction in isolated frog skeletal muscle fiber via a sodium-carrying mechanism, Inoue and Frank proposed that general and LAs acted via a unitary molecular mechanism in all excitable cells of the nervous system (Inoue and Frank, 1962; Frank and Sanders, 1963; Frank and Pinsky, 1966).

Motivated by the well-known positive correlation discovered between a compound's solubility in olive oil and anesthetic potency (Meyer, 1899; Overton, 1901; Harris and Bruno, 1985), research on the mechanism of anesthetic action during the 1970s focused on a nonspecific drug perturbation of the lipid bilayer. It was proposed that volatile anesthetics acted on the lipid bilayer causing a lipid fluidization of the cell membrane, resulting in the depression of neurotransmission and eventually unconsciousness. Fluidization of the membrane was thought to cause distortions of membrane proteins (with an emphasis on ion channels such as $\mathrm{Na}^{+}$ channels), leading to a block of $\mathrm{Na}^{+}$conductance and a breakdown of signaling in excitable cells of the central nervous system (Seeman, 1972). Phillip Seeman's hypothesis is regarded as one of the first proposing VGSCs as specific targets of volatile anesthetic action (Seeman, 1974).

Early voltage-clamp studies of the late 1970 s and early 1980 s, using the voltage-clamp technique in frog, crayfish, and squid giant axon, showed that diethyl ether reduced peak $\mathrm{Na}^{+}$current by accelerating VGSC inactivation, but with little to no effect at concentrations of clinical relevance (Bean, 1979; Kendig et al., 1979; Bean et al., 1981; Haydon and Urban, 1983, 1986; Urban and Haydon, 1987; Elliott et al., 1992). When investigating the effect of diethyl ether and the haloalkane halothane on $\mathrm{Na}^{+}$current in the crayfish giant axon, Bean et al. (1981) observed a minor concentrationdependent enhancement of inactivation at all membrane potentials. Ether produced a hyperpolarizing shift in steady-state inactivation but did not alter the time-dependent recovery from inactivation, nor did it affect frequency-dependent stimulation (Bean et al., 1981).

Haydon and Urban (1983) reached similar conclusions when investigating the squid giant axon. No significant difference was found in membrane capacitance or $\mathrm{Na}^{+}$conductance. Steady-state inactivation was shifted by a few millivolts in the hyperpolarizing 
direction (Haydon and Urban, 1983). The effect of ether, halothane, and enflurane inhibition on $\mathrm{Na}^{+}$uptake using rodent brain synaptosomes was evaluated by Harris and Bruno (1985). All three of the anesthetics caused a $10 \%-20 \%$ reduction in $\mathrm{Na}^{+}$uptake (Harris and Bruno, 1985).

According to the lipid-based hypotheses, anesthetics would be adsorbed by the bilayer, increasing membrane thickness, which would inhibit ion channels and subsequently axonal conduction (Franks, 2006). Controversy ensued when it was observed that the anestheticinduced hyperpolarizing shift in sodium channel steady-state inactivation could not be due to the minor perturbations of bilayer thickness (Franks and Lieb, 1978, 1979, 1981; Elliott et al., 1984). Nicholas Franks and William Lieb demonstrated that anesthetics could act in a lipid-free environment, which brought lipid fluidization into question as the mechanism of anesthetic action (Franks and Lieb, 1981, 1982, 1984),. They proposed that direct interactions with membrane proteins were responsible for anesthetic action at a molecular level. They did not, however, believe that VGSCs were among the main proteins targeted. Before dismissing the involvement of VGSCs in their landmark Nature review, Franks and Lieb (1994) conceded the plausibility of even minor ion channel modulation disrupting communication between neurons.

A unitary hypothesis of general anesthetic action based on membrane fluidization is now widely regarded as misleading. Changes in temperature cause similar effects as general anesthetics on the properties of the cell membrane, but do not alter consciousness. Herold et al. (2014) showed that volatile anesthetics inhibit VGSCs independent of any action on the lipid bilayer of the cell membrane. Recent studies by Herold et al. $(2017 a, b)$ examined the effects of a range of structurally diverse general anesthetics on lipid bilayer properties using a gramicidin-based fluorescence assay. The authors observed no detectable effects on lipid bilayer properties at clinically relevant concentrations of most anesthetics tested, with only minimal perturbations seen in some halogenated ethers or at supratherapeutic concentrations of the agents tested (Herold et al., $2017 a, b)$. These findings provide strong support for the notion that general anesthetics act directly on membrane proteins to produce their clinical effects, excluding indirect ion channel modulation as a pharmacologically relevant mechanism.

Molecular advances and cloning techniques permitted the analysis of isolated VGSC isoforms expressed in mammalian cells or other heterologous systems such as Xenopus oocytes. Using rat brain IIA $\left(\mathrm{Na}_{\mathrm{v}} 1.2\right)$ channels stably expressed in Chinese hamster ovary cells, Rehberg et al. (1996) were among the first to publish recordings showing halogenated ether activity with a specific VGSC isoform. All agents tested caused a reduction of peak $\mathrm{Na}^{+}$current and a hyperpolarizing shift in the half-maximal voltage $\left(\mathrm{V}_{1 / 2}\right)$ of steady-state inactivation. The hyperpolarizing shift in the $\mathrm{V}_{1 / 2}$ of inactivation ranged from -20 to $-25 \mathrm{mV}$, depending on the volatile anesthetic tested and holding potential of the protocol (Rehberg et al., 1996). Duch et al. (1998) confirmed this, reporting a similar reduction in peak $\mathrm{Na}^{+}$current and a hyperpolarizing shift of inactivation with whole-cell recordings testing isoflurane in rat dorsal root ganglion neurons. Stadnicka et al. (1999) tested isoflurane and halothane on human embryonic kidney cells expressing human $\mathrm{Na}_{\mathrm{v}} 1.5$ (hH1a) and concluded both agents preferentially inhibit the inactivated state of $\mathrm{Na}_{\mathrm{v}} 1.5$.

Why did the early electrophysiologists see no conduction block in response to halogenated ethers at similar concentrations to those used in the experiments above? The diminished effect seen with early voltage-clamp recordings of halogenated ethers may be specific to the experimental preparation (i.e., squid giant axon vs. mammalian cell line). Experimental conditions used with invertebrate preparations-including ion concentrations, recording temperature, ion channel expression patterns, and numerous other factors-can complicate the translation of results to mammalian physiology. A potential explanation is the large reserve of VGSCs present in axons, in which perturbations are likely to affect spike-timing precision and conduction velocity, but unlikely to result in overt action failure. Although axons contain the highest density of VGSCs in neurons, as discussed previously, VGSCs are expressed in a controlled manner in a variety of subcellular and cell type-specific contexts. Furthermore, as discussed above regarding neuromodulation, VGSCs exhibit differential sensitivity based on a variety of context-dependent factors, including neuromodulation, membrane potential, and isoform type.

To address this question, Ouyang et al. (2003) performed patch-clamp recordings in isolated rat neurohypophysial nerve terminals. Both isoflurane (and the intravenous anesthetic propofol) blocked $\mathrm{Na}^{+}$current at clinically relevant concentrations. Isoflurane inhibited peak $\mathrm{Na}^{+}$current with an $\mathrm{IC}_{50}$ of $0.45 \mathrm{mM}$ when holding the voltage of the membrane at $-70 \mathrm{mV}$ $\left(\mathrm{V}_{\mathrm{h}}-70 \mathrm{mV}\right)$ and $0.56 \mathrm{mM}\left(\mathrm{V}_{\mathrm{h}}-90 \mathrm{mV}\right)$. Isoflurane did not alter activation kinetics, but did cause a hyperpolarizing shift of the $\mathrm{V}_{1 / 2}$ of inactivation ( $-14 \mathrm{mV}$ with a 30-ms prepulse protocol) (Ouyang et al., 2003). The $\mathrm{IC}_{50}$ values seen in the terminals were lower than previously reported (Rehberg et al., 1996; Duch et al., 1998). This indicates several possibilities, including differential inhibition of VGSC isoforms, neuromodulatory state dependence, or modulation of channel sensitivity by accessory VGSC proteins. VGSC $\alpha$-subunit isoforms expressed in Chinese hamster ovary or human embryonic kidney cells do not possess the same VGSC accessory proteins present in rat neurohypophysial nerve terminals, although some 
cell lines exhibit background $\beta$-subunit expression (Calhoun and Isom, 2014).

Using the two-electrode voltage-clamp technique, Shiraishi and Harris (2004) measured $\mathrm{Na}^{+}$current in Xenopus oocytes expressing rat $\mathrm{Na}_{\mathrm{v}} 1.2$, human $\mathrm{Na}_{\mathrm{v}} 1.4$, rat $\mathrm{Na}_{\mathrm{v}} 1.6$, or rat $\mathrm{Na}_{\mathrm{v}} 1.8$. They also coexpressed rat $\beta 1$-subunits, although their presence did not alter any channel's sensitivity to the anesthetics tested. Isoflurane inhibited peak $\mathrm{Na}^{+}$current in oocytes expressing rat $\mathrm{Na}_{\mathrm{v}} 1.2$, human $\mathrm{Na}_{\mathrm{v}} 1.4$, or rat $\mathrm{Na}_{\mathrm{v}} 1.6$ by $\sim 30 \%$ (Shiraishi and Harris, 2004). The effect of isoflurane was more pronounced at depolarized holding potentials. The TTX-resistant isoform $\mathrm{Na}_{\mathrm{v}} 1.8$ was found to be insensitive to isoflurane at concentrations up to twice the minimum alveolar concentration (defined as the concentration at which $50 \%$ of subjects do not respond with movement to noxious stimuli) (Shiraishi and Harris, 2004). A later study using the rodent neuronal expression system, ND7/23 cells, expressing rat $\mathrm{Na}_{\mathrm{v}} 1.8$, showed that $\mathrm{Na}_{\mathrm{v}} 1.8$ is sensitive to isoflurane in this expression system. At $\left(\mathrm{V}_{\mathrm{h}}-70\right), 1.8$ minimum alveolar concentration (MAC) blocked $\sim 55 \%$ of $\mathrm{Na}_{\mathrm{v}} 1.8$ mediated current $\left(\mathrm{IC}_{50} 0.67 \pm 0.06 \mathrm{mM}\right.$ ) (Herold et al., 2009). The discrepancy seen in oocytes versus the ND7/ 23 line indicates the importance of a native neuronal environment, suggesting a potential role for nonporeforming $\beta$-subunit proteins, cytoskeletal environment, or post-translational modification (e.g., phosphorylation) in VGSC sensitivity to halogenated ethers. Similar results of cell line- and cell type-specific modulation of VGSC function and expression are observed with VGSC $\beta$-subunits, suggesting a general need to investigate VGSC function in a physiologic and precisely defined context. Of note is that aromatic volatile anesthetics like fluorobenzene are also observed to cause significant inhibition of $\mathrm{Na}^{+}$current in Xenopus oocytes (Horishita et al., 2008).

Ouyang and Hemmings (2007) tested the selectivity of isoflurane on Chinese hamster ovary cells stably expressing rat $\mathrm{Na}_{\mathrm{v}} 1.2$, rat $\mathrm{Na}_{\mathrm{v}} 1.4$, or rat $\mathrm{Na}_{\mathrm{v}} 1.5 . \mathrm{Na}^{+}$ current was significantly reduced, and a hyperpolarizing shift in steady-state inactivation was seen in all three isoforms. Importantly, isoflurane displayed selective blocking properties between isoforms. At $\mathrm{V}_{\mathrm{h}}-100$ $\mathrm{mV}$, tonic block was observed for all three isoforms. When holding at $\mathrm{V}_{\mathrm{h}}-70 \mathrm{mV}$, enhanced inactivation became the dominant mechanism of isoflurane inhibition of rat $\mathrm{Na}_{\mathrm{v}} 1.4$ - and rat $\mathrm{Na}_{\mathrm{v}} 1.5$-mediated $\mathrm{Na}^{+}$current (Ouyang and Hemmings, 2007).

Isoflurane, sevoflurane, enflurane, desflurane, and the haloalkane halothane were tested via whole-cell patch clamp from Chinese hamster ovary cells stably expressing rat $\mathrm{Na}_{\mathrm{v}} 1.4$ (Ouyang et al., 2009). Each anesthetic at $\sim 1$ MAC significantly inhibited peak $\mathrm{Na}^{+}$current. Peak current was elicited by a $25-\mathrm{ms}$ step $\left(\mathrm{V}_{\mathrm{h}}\right.$ of $\left.-80 \mathrm{mV}\right)$ to -10 or $-20 \mathrm{mV}$. Reduction in peak $\mathrm{Na}^{+}$current by isoflurane and sevoflurane: $14 \%$; enflurane: $28 \%$; and desflurane: $48 \%$ (see Fig. 4). Consistent with previous reports, each of the halogenated ethers and halothane caused a significant hyperpolarizing shift in the $\mathrm{V}_{1 / 2}$ of inactivation at $\sim 1$ MAC (Ouyang et al., 2009). The differential agent-specific inhibition displayed by the halogenated ethers is important. The higher relative ability of desflurane in blocking $\mathrm{Na}^{+}$ current compared with the other halogenated ethers is notable. The underlying mechanism of desflurane's increased VGSC conduction inhibition is currently unknown.

Yokoyama et al. (2011) tested the effects of sevoflurane on rat $\mathrm{Na}_{\mathrm{v}} 1.4-$, human $\mathrm{Na}_{\mathrm{v}} 1.7-$, and rat $\mathrm{Na}_{\mathrm{v}} 1.8-$ mediated current expressed in oocytes. Sevoflurane (0.5 $\mathrm{mM}$ ) did not cause a shift in activation or inactivation, nor did it influence peak current. Sevoflurane $(1 \mathrm{mM})$ also did not change the current-voltage relationship, but did significantly inhibit the peak $\mathrm{Na}^{+}$current of all three isoforms by $15 \%-19 \%$. The authors hypothesized that sevoflurane inhibits VGSCs through a PKCmediated pathway. Pretreatment with bisindolylmaleimide, a PKC inhibitor, reversed the effect of sevoflurane on all isoforms (Yokoyama et al., 2011).

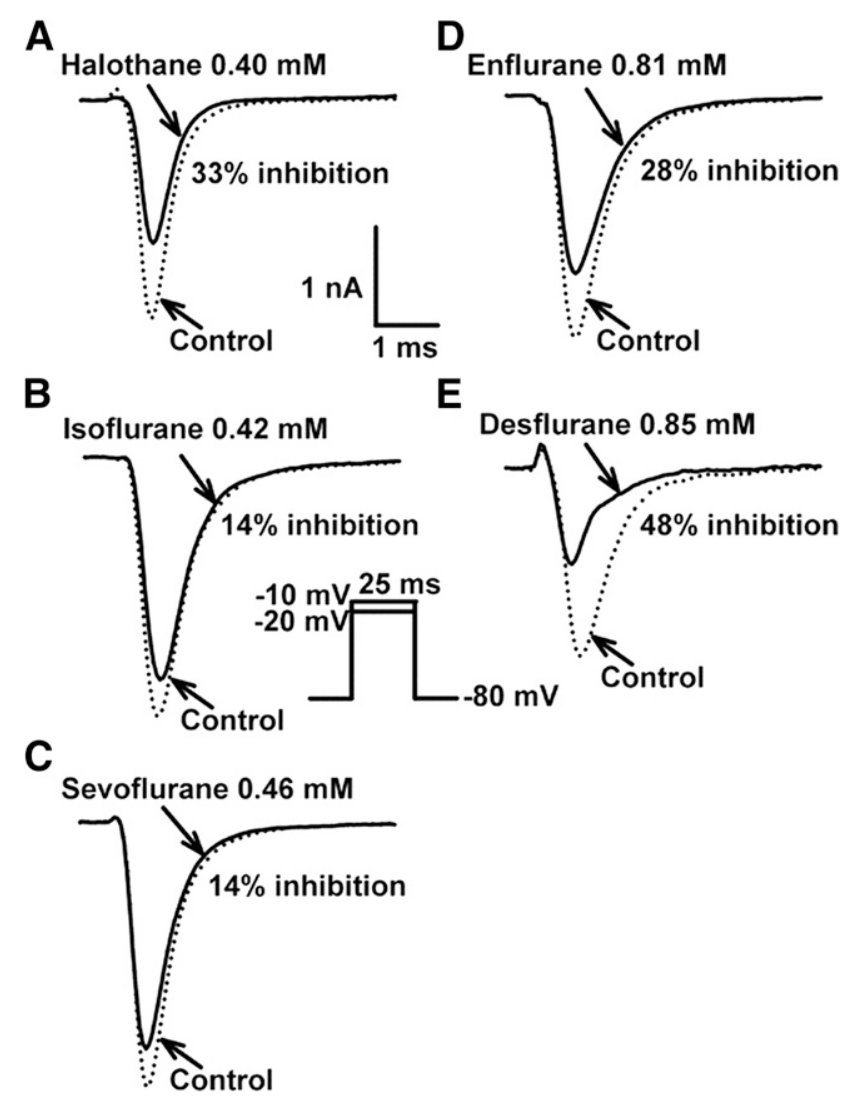

Fig. 4. The halogenated ethers show differential inhibition of whole-cell $\mathrm{Na}^{+}$current in Chinese hamster ovary cells expressing rat $\mathrm{Na}_{\mathrm{v}} 1.4$ at 1 MAC. (A) Halothane; (B) isoflurane; (C) sevoflurane; (D) enflurane; (E) desflurane. Currents were evoked via $25-\mathrm{ms}$ depolarizing pulses from a holding potential of -80 to -20 or $-10 \mathrm{mV}$. Reproduced with permission from Ouyang et al. (2009). 


\section{Structural and Computational Studies Using Prokaryotic Voltage-Gated Sodium Channels}

The successful crystallization of a eukaryotic VGSC has yet to be accomplished. Therefore, the exact amino acid residues of the human VGSCs that the halogenated ethers interact with can only be inferred. However, prokaryotic VGSCs such as $\mathrm{Na}_{\mathrm{v}} \mathrm{AB}$ from Arcobacter butzleri, $\mathrm{Na}_{\mathrm{v}} \mathrm{Ms}$ from Magnetococcus marinus, and $\mathrm{Na}_{\mathrm{v}} \mathrm{Rh}$ from Rickettsiales sp. HIMB114 have been crystallized (Payandeh et al., 2011; McCusker et al., 2012; Zhang et al., 2012). These bacterial sodium channels serve as powerful models to study the structure and function of eukaryotic VGSCs.

One bacterial sodium channel known as NaChBac, which has not yet been crystallized, from Bacillus halodurans is considered an exemplar that has been used as a model on which to base hypotheses of halogenated ether binding to a eukaryotic channel. Like all other bacterial VGSCs studied to date, NaChBac contains a single domain with six-transmembrane $\alpha$-helices (see Fig. 5) (Catterall, 2001). Despite being one-tenth the amino acid size of a mammalian VGSC, $\mathrm{NaChBac}$ still conserves many of its integral functions. The channel similarly activates in response to voltage changes. Both activation and inactivation kinetics are slower for NaChBac compared with mammalian channels. The $\mathrm{Na}^{+}$selectivity mechanism consists of a symmetric glutamate (EEEE) motif. This selectivity mechanism is used by voltage-gated calcium channels and diverges from the mammalian DEKA motif (Lipkind and Fozzard, 2008). Interestingly, NaChBac is not blocked by TTX, but is sensitive to the L-type calcium channel blocker class of dihydropyridines (Charalambous and Wallace, 2011). Its small size and homotetrameric organization make it a powerful tool to study VGSC structure, function, and pharmacology.

Ouyang et al. (2007) performed whole-cell patchclamp recordings with isoflurane on human embryonic kidney cells expressing $\mathrm{NaChBac}$. Isoflurane caused a concentration-dependent inhibition of peak $\mathrm{Na}^{+}$ current $\left(\mathrm{IC}_{50}=0.35 \mathrm{mM}\right.$ at $\left.\mathrm{V}_{\mathrm{h}}=-80 \mathrm{mV}\right)$. Both activation and inactivation kinetics were altered. At clinically relevant concentrations, isoflurane positively shifted the voltage dependence of activation. Consistent with earlier reports, isoflurane also shifted the $V_{1 / 2}$ of $\mathrm{NaChBac}$ inactivation in the hyperpolarizing direction. The investigators found $\mathrm{NaChBac} 8$-fold more susceptible to isoflurane-induced enhanced inactivation compared with tonic block of the activated state of the channel (Ouyang et al., 2007). This NaChBac study provides important evidence of phylogenetic conservation for halogenated ether binding to VGSCs.

Raju et al. (2013) performed molecular dynamics simulations of isoflurane binding to $\mathrm{NaChBac}$ and proposed three distinct binding sites that emerge at clinically relevant concentrations. The first is an extracellular site at "the intersubunit interface between the P-loops" (Raju et al., 2013). The second is a linker site between the $\mathrm{N}$ and $\mathrm{C}$ termini. The authors hypothesized that multiple isoflurane molecules occupy this site simultaneously, with mainly nonpolar drug-channel interactions. The third site was deemed the pore site. Even though the molecular dynamics simulations were carried out with the activation gate of $\mathrm{NaChBac}$ closed, isoflurane was still able to access the ionic pore to form hydrophobic interactions with the channel. Two of these residues (T220 and F227) align with residues from mammalian VGSCs that are known to mediate LA binding (F1764 and $\mathrm{Y} 1771$ rat $\mathrm{Na}_{\mathrm{v}} 1.2$ numbering) (Raju et al., 2013).

Using a combination of electrophysiology and molecular dynamics simulations, Barber et al. (2014) proposed that sevoflurane caused open channel blockade while also altering the activation and inactivation kinetics of $\mathrm{NaChBac}$. Sevoflurane $(0.2 \mathrm{mM})$ caused $\mathrm{a}-10 \mathrm{mV}$ shift in the $\mathrm{V}_{1 / 2}$ of activation and $\mathrm{a}-14 \mathrm{mV}$ shift in the $\mathrm{V}_{1 / 2}$ of inactivation. This resulted in a $\sim 15 \%$ increase in peak $\mathrm{Na}^{+}$current at $0.2 \mathrm{mM}$ sevoflurane and a $\sim 7 \%$ decrease at $2 \mathrm{mM}$ (Barber et al., 2014). Sevoflurane also accelerated the timedependent recovery from inactivation, whereas

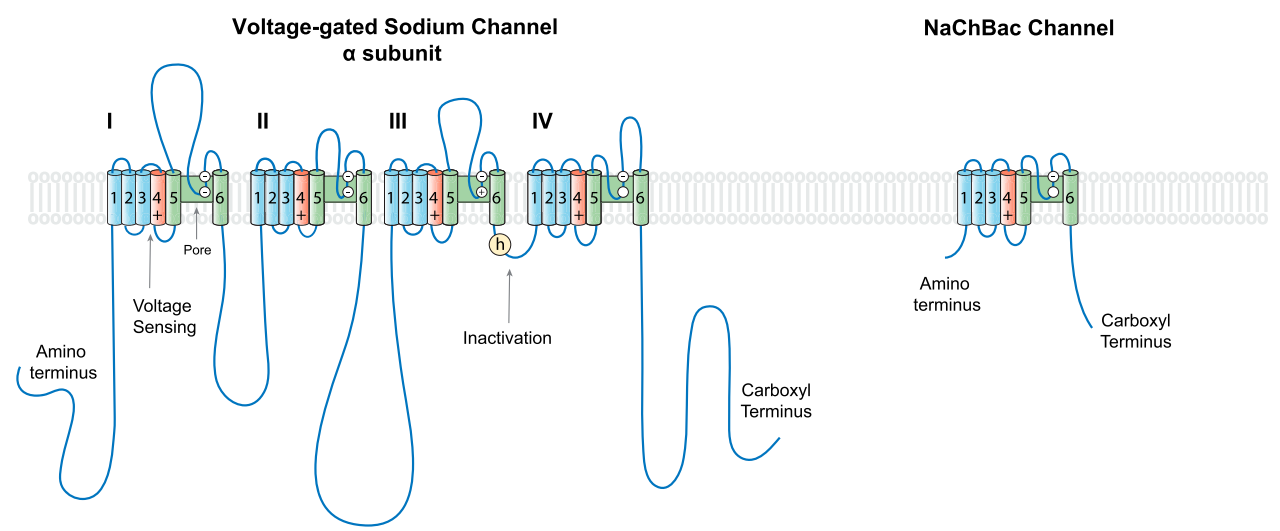

Fig. 5. Comparing the eukaryotic and prokaryotic VGSC structures. (Left) Two-dimensional schematic of the eukaryotic VGSC $\alpha$-subunit. (Right) Twodimensional schematic of NaChBac, the prokaryotic VGSC $\alpha$-subunit found in Bacillus halodurans. 
previous studies with halogenated ethers and mammalian VGSCs showed a delay in recovery from inactivation. Molecular dynamics simulations indicated sevoflurane binding to multiple sites. The authors noted a state-dependent interaction with the central cavity of the pore, leading them to emphasize an open channel block. Consistent with the findings of Raju et al. (2013), residues involved in LA binding (F1764 and Y1771 rat $\mathrm{Na}_{\mathrm{v}} 1.2$ numbering) were highlighted by Barber et al. (2014) as sevoflurane binding sites.

Kinde et al. (2016) sought to experimentally validate binding of isoflurane to $\mathrm{NaChBac}$ by nuclear magnetic resonance. ${ }^{19} \mathrm{~F}$ probes were inserted into critical residues of the three putative binding sites (extracellular site, pore site, and linker site) suggested by the computational studies (Raju et al., 2013; Barber et al., 2014). ${ }^{19} \mathrm{~F}$ NMR saturation transfer spectroscopy confirmed multiple major sites of isoflurane interaction with $\mathrm{NaChBac}$. The study revealed two primary mechanisms by which isoflurane inhibits the channel. One mechanism is at the inner ring of the selectivity filter, occluding the pore. The other is at a hinge site, in which isoflurane binds to the S4-S5 linker that controls inactivation gating via interactions with S6 (Kinde et al., 2016).

The effects of isoflurane of NaChBac gating via sitedirected mutagenesis were recently explored (Sand et al., 2017). After expressing $\mathrm{NaChBac}$ in human embryonic kidney cells, two point mutations were introduced to residues involved in activation: G229A, which inhibits activation, and G219A, which enhances activation. Their analysis suggested isoflurane primarily inhibits $\mathrm{NaChBac}$ via enhanced activation and inactivation, not through an open channel block of $\mathrm{NaChBac}$ (Sand et al., 2017).

A recent study using whole-cell patch clamp examining the effects of propofol on $\mathrm{NaChBac}$ showed that this anesthetic also inhibits peak $\mathrm{Na}^{+}$current of the prokaryotic channel at clinically relevant concentrations (Yang et al., 2018). The authors propose that propofol acts via a hyperpolarizing shift in steady-state inactivation. Molecular dynamics simulations with propofol suggest it directly interacts with $\mathrm{NaChBac}$ at multiple distinct sites on the channel (Wang et al., 2018). These results indicate that VGSC inhibition may be involved in the mechanism of action of anesthetic agents beyond the halogenated ethers.

\section{Presynaptic Voltage-Gated Sodium Channel Inhibition Leads to Depressed Neurotransmission}

What are the neurochemical consequences of activitydependent VGSC inhibition by halogenated ethers? Hemmings (2009) has proposed a mechanism by which presynaptic VGSC inhibition leads to reduced depolarization of the presynaptic terminal. The VGSC inhibition reduces $\mathrm{Ca}^{2+}$ influx into the terminal via voltage-gated calcium channels (Hemmings, 2009). Reduced $\mathrm{Ca}^{2+}$ influx ultimately leads to reduced exocytosis and neurotransmission (see Fig. 6). Previous studies have revealed that isoflurane and other volatile anesthetics suppress synaptic vesicle exocytosis and neurotransmission via presynaptic actions (Schlame and Hemmings, 1995; Maclver et al., 1996; Hemmings et al., 2005a; Ouyang and Hemmings, 2005). Due to most neurons in the human brain utilizing glutamatergic neurotransmission, this mechanism would have important consequences for neural networks if occurring during volatile anesthesia in vivo.

Studies conducted by Berg-Johnsen and Langmoen (1986, 1990, 1992) revealed a depression of neuronal excitability and excitatory synaptic transmission by isoflurane in the rat hippocampus and human neocortex. Using isolated rat cerebrocortical nerve terminals, Westphalen and Hemmings (2006a,b) showed that isoflurane inhibition of presynaptic VGSCs was more highly coupled to glutamate release than GABA. By measuring the release of radiolabeled glutamate and GABA evoked by either 4-aminopyridine (4-AP; VGSCdependent release) or elevated levels of extracellular $\mathrm{K}^{+}$ (VGSC-independent release), the investigators found the VGSC-dependent release using 4-AP more sensitive to inhibition by isoflurane than VGSC-independent release

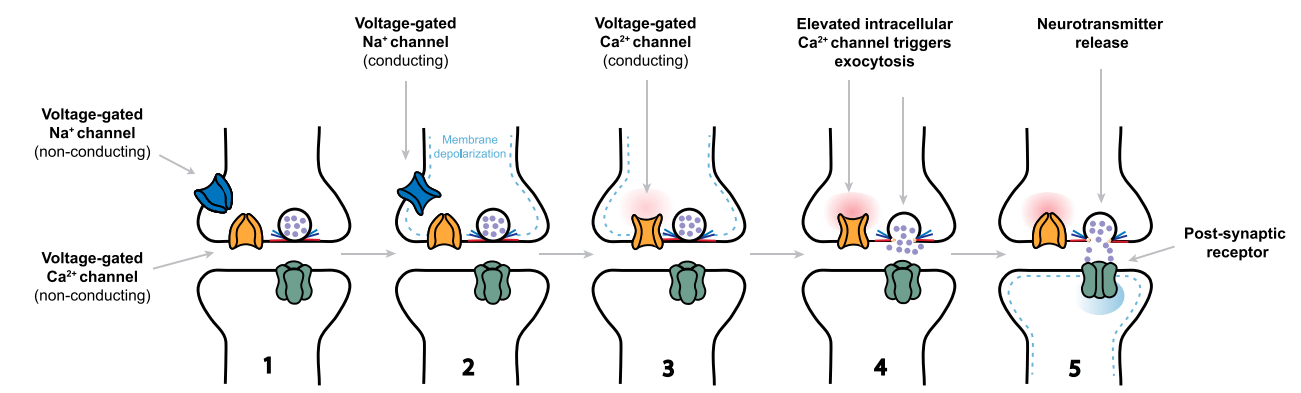

Fig. 6. Basic overview of voltage-gated $\mathrm{Na}^{+}$channels in synaptic transmission. (1) At rest, presynaptic voltage-gated $\mathrm{Na}^{+}$and $\mathrm{Ca}^{2+}$ channels are closed. (2) Voltage-gated $\mathrm{Na}^{+}$channels open, driving membrane depolarization and action potential propagation. (3) Voltage-gated Ca ${ }^{2+}$ channels open, raising intracellular levels of $\mathrm{Ca}^{2+}$. (4) Elevated intracellular $\mathrm{Ca}^{2+}$ triggers exocytosis. (5) Neurotransmitters are released into the synaptic cleft, activating postsynaptic receptors leading to a depolarization of the postsynaptic membrane. Due to the instrumental role voltage-gated $\mathrm{Na}^{+}$channels play in this process, their inhibition by the halogenated ethers is likely to lead to dysfunction in neurotransmitter release. 
using elevated extracellular $\mathrm{K}^{+}$. Moreover, the $\mathrm{IC}_{50}$ values for 4-AP-evoked release support the preferential inhibition of isoflurane for glutamate over GABA release. Isoflurane $\mathrm{IC}_{50}$ values of 4 -AP-evoked release were 0.44 and $0.58 \mathrm{mM}$ for glutamate and GABA, respectively (Westphalen and Hemmings, 2003; Hemmings, 2009).

Additionally, even a small inhibition of the action amplitude in the presynaptic terminal induced by isoflurane inhibits excitatory postsynaptic current amplitude and exocytosis in the rat calyx of Held synapse with no significant effect on $\mathrm{Ca}^{2+}$ currents. Wu et al. (2004) reported that a majority $(\sim 70 \%)$ of the isoflurane-induced inhibition of the excitatory postsynaptic current resulted from inhibition of the presynaptic action potential. In cultured rat hippocampal neurons, isoflurane significantly inhibits synaptic vesicle exocytosis through a reduction in presynaptic $\mathrm{Ca}^{2+}$ influx without affecting the $\mathrm{Ca}^{2+}$ sensitivity of exocytosis. This effect was more pronounced when targeting glutamatergic over GABAergic neurons (Baumgart et al., 2015).

It has long been observed that ether and some halogenated derivatives display a depression of excitatory synaptic transmission that varies in different brain regions (Richards and White, 1975; Richards et al., 1975). The suppression of neurotransmitter release by isoflurane was shown to have regional specificity (Westphalen et al., 2011). This regional specificity could, in part, result from the differential localization of VGSC subtypes within nerve terminals of different cell types and their expression patterns within various regions of the brain (Westphalen et al., 2010). Isoflurane was recently shown to inhibit persistent and transient $\mathrm{Na}^{+}$current in hippocampal excitatory pyramidal neurons from mice at clinically relevant concentrations (Zhao et al., 2019). Moreover, the differential localization of VGSC subtypes in pre- and postsynaptic compartments most likely contributes to localized variations in neurotransmitter suppression observed (Johnson et al., 2017).

\section{In Vivo Modulation of Halogenated Ether Anesthesia}

\section{A. Modulation of Anesthetic Sensitivity Mediated by Pharmacological Manipulation of Voltage-Gated Sodium Channels}

Evidence of VGSC involvement in the action of volatile anesthetics came from a study of two structurally similar fluorinated cyclobutanes by Ratnakumari et al. (2000). Only one of these compounds showed anesthetic capability: the anesthetic compound F3 (1-chloro-1,2,2-trifluorocyclobutane) versus the nonanesthetic compound F6 (1,2-dichlorohexafluorocyclobutane). $\mathrm{Na}^{+}$current was measured using whole-cell patch clamp in rat dorsal root ganglia neurons. Compound F3 induced a $70 \% \pm 9 \%$ reduction in peak $\mathrm{Na}^{+}$ current at 0.6 MAC, whereas the nonanesthetic compound $\mathrm{F} 6$ only caused a $16 \% \pm 2 \%$ reduction in peak $\mathrm{Na}^{+}$current at the predicted 1 MAC (Ratnakumari et al., 2000). The authors then used the voltage-gated $\mathrm{K}^{+}$ channel blocker 4-AP and the VGSC activator veratridine to assess the VGSC dependence of glutamate release by compound F3 or F6. The anesthetic compound F3 significantly inhibited VGSC-dependent glutamate release and significantly inhibited veratridine-evoked increases in intracellular $\mathrm{Ca}^{2+}$. The nonanesthetic $\mathrm{F} 6$ had no significant effects at the concentrations tested (Ratnakumari et al., 2000). Ratnakumari et al. (2000) further investigated the role of VGSCs in the volatile anesthetic depression of glutamate release from synaptosomes prepared from three different mammalian species (Lingamaneni et al., 2001). Isoflurane (and propofol) preferentially inhibited veratridine-evoked, as opposed to high $\mathrm{KCl}$-evoked, glutamate release. The authors used this result to suggest that interruption of presynaptic VGSC coupling to glutamate release is more relevant to anesthesia than $\mathrm{Ca}^{2+}$ channel-dependent glutamate release. Shiraishi and Harris (2004) measured the blocking capacity of compound F3 and compound $\mathrm{F} 6$ on rat $\mathrm{Na}_{\mathrm{v}} 1.2$-mediated current. The anesthetic compound F3 inhibited peak $\mathrm{Na}^{+}$current by $7 \% \pm 2 \%\left(\mathrm{~V}_{\mathrm{h}}-90 \mathrm{mV}\right)$ and $34 \% \pm 5 \%\left(\mathrm{~V}_{\mathrm{h}}-60 \mathrm{mV}\right)$, whereas the nonanesthetic $\mathrm{F} 6$ had no measurable effects (Shiraishi and Harris, 2004).

1. Overlap with Local Anesthetic Mechanism of Action. Infusion of the LA lidocaine significantly increases the anesthetic potency of isoflurane in rats (Zhang et al., 2007). Use-dependent LA drugs like lidocaine bind rapidly, preferentially blocking the open (activated) state of the VGSC. The term "usedependent" means that the degree of channel block is proportional to the firing frequency of the neuron. Neurons firing repetitively quickly accumulate sodium channels in the open state, increasing the blocking effects of lidocaine, rendering them incapable of firing. The primary LA site has been determined to consist of residues located on the S6 segment of domains I, III, and IV (Catterall, 2012). Lingamaneni and Hemmings (2003) also showed that isoflurane and enflurane interact with the LA site of neuronal VGSCs by competition binding of $\left[{ }^{3} \mathrm{H}\right]$-batrachotoxinin A $20-\alpha$ benzoate to rat cerebrocortical synaptosomes.

Bertil Hille proposed another access pathway for LA drugs in his modulated receptor hypothesis in the 1970s. Hille posited that fenestrations in the lipid bilayer of the membrane provide LA drugs hydrophobic access to the receptor site when the channel is inactivated. This hypothesis is supported in the features of the bacterial VGSC $\mathrm{Na}_{\mathrm{v}} \mathrm{Ab}$ via analysis of the crystal structure by Payandeh et al. (2011). It is possible that the halogenated ethers act on VGSCs via these fenestrations similarly to LAs. Of note is that the $\beta 1$ - and $\beta 3$ subunits attenuate the binding of lidocaine to $\mathrm{Na}_{\mathrm{v}} 1.3$, further supporting the hypothesis that the action of 
halogenated ethers may similarly act in a contextdependent manner on VGSCs present in the central nervous system.

Xing et al. (2003) showed that intrathecal and intravenous infusion of the Food and Drug Administrationapproved sodium channel blocker riluzole significantly decreased the MAC for isoflurane and halothane. Veratridine is a steroidal alkaloid that acts as an activator for VGSCs (Barnes and Hille, 1988). The toxin persistently activates the channel by shifting the activation threshold to more negative potentials (Barnes and Hille, 1988). Zhang et al. (2008) found that intrathecal administration of $1.6 \mu \mathrm{M}$ veratridine caused a $\sim 21 \%$ increase in isoflurane MAC. In a followup study, Zhang et al. (2010) showed this effect to be reversible with intrathecal administration of TTX. TTX has a high affinity for neurotoxin receptor site on one of the TTX-sensitive VGSCs, occluding the pore. Intrathecal infusion of $0.63 \mu \mathrm{M}$ TTX decreased the MAC of isoflurane in rats by more than 50\% (Zhang et al., 2010). The consistent increase in halogenated ether potency with coadministration of structurally diverse VGSC blockers and the ability to antagonize that effect with the channel activator veratridine provides pharmacological evidence of VGSC mediation of halogenated ether immobilization.

\section{B. Modulation of Anesthetic Sensitivity Mediated by Genetic Manipulation of Voltage-Gated Sodium Channels}

$\mathrm{Na}_{\mathrm{v}} 1.6$ (encoded by $S C N 8 A$ ) is the most abundantly expressed VGSC subtype in the adult central nervous system (Goldin, 2001). The subtype is highly localized to the neuronal axon initial segment and nodes of Ranvier (Lorincz and Nusser, 2010). As a major contributor to neuronal excitability, $\mathrm{Na}_{\mathrm{v}} 1.6$ is a subtype of interest in halogenated ether anesthesia. Pal et al. (2015) showed that $\mathrm{Na}_{\mathrm{v}} 1.6$ was important for mediating in vivo sensitivity to isoflurane and sevoflurane anesthesia induction. Using mice with reduced $\mathrm{Na}_{\mathrm{v}} 1.6$ activity (SCN8A $A^{\text {medJ/medJ }}$ and $S C N 8 A^{9 J / 9 J}$ mice), the authors found the mutant mice to be significantly more sensitive to isoflurane and sevoflurane than their wild-type littermate controls (see Fig. 7). The $S C N 8 A^{\text {medJ/medJ }}$ mutation does not change the amino acid sequence, but reduces expression levels of $\mathrm{Na}_{\mathrm{v}} 1.6$ by $90 \%-95 \%$ of that of wild-type levels by disrupting splicing efficiency. The $S C N 8 A^{9 J / 9 J}$ mutation is an in-frame deletion in segment 6 of domain IV, resulting in a dramatic decrease in channel activity (Pal et al., 2015). The concentration required for $50 \%$ of tested mice to lose their righting reflex $\left(\mathrm{IC}_{50}\right)$ was significantly lower for the $S C N 8 A^{\text {medJ/medJ }}$ and $S C N 8 A^{9 J / 9 J}$ mice compared with their littermate controls.

Notably, the time to emerge from anesthesia (return of righting reflex) was not different in the mutant mice versus control under isoflurane. There was a significant difference in the return of righting reflex after sevoflurane for $S C N 8 A^{9 J / 9 J}$ mice versus wild-type. Intracranial electroencephalogram was performed on the mice. Significant reductions in $\theta$ power for both $S C N 8 A^{\text {medJ/medJ }}$ and $S C N 8 A^{9 J / 9 J}$ mice in the waking state compared with controls excluded sleep deprivation as an explanation for the increased anesthetic sensitivity. Increased $\theta$ power is a marker for sleep deprivation in the waking state of mice. The differential effect on induction sensitivity supports a potential role for VGSC involvement in the maintenance of consciousness. The authors noted that differential expression patterns of $\mathrm{Na}_{\mathrm{v}} 1.6$ could lead to nonspecific physiologic effects (Pal et al., 2015).

An accumulating body of evidence indicates halogenated ethers inhibit sodium channels via stabilization of the fast-inactivated state. Purtell et al. (2015) used the prototypical halogenated ether isoflurane to further investigate this effect on rat $\mathrm{Na}_{\mathrm{v}} 1.2$-mediated sodium current in ND7/23 cells. To eliminate the endogenous VGSC current in the neuronal rodent line, a phenylalanine to serine mutation (F385S) was introduced to rat $\mathrm{Na}_{\mathrm{v}} 1.2$ to render it TTX resistant, and whole-cell recordings were performed in the presence of $250 \mathrm{nM}$ TTX. A modest reduction of peak $\mathrm{Na}^{+}$current $(\sim 10 \%)$ was observed at 1.5 MAC isoflurane. A $\sim 4 \mathrm{mV}$ shift in the $\mathrm{V}_{1 / 2}$ of steady-state inactivation was seen with no alterations in activation. The time-dependent recovery from inactivation was delayed following treatment with 1.5 MAC (Purtell et al., 2015). After observing that the delayed recovery from inactivation was more pronounced at depolarized holding potentials, the authors tested the activity-dependent effects of isoflurane. Following 10 depolarizing $5-\mathrm{ms}$ pulses at $50 \mathrm{~Hz}\left(\mathrm{~V}_{\mathrm{h}}\right.$ of -70 or -90 stepping to $0 \mathrm{mV}$ ), $1.5 \mathrm{MAC}$ isoflurane significantly reduced the fraction of $\mathrm{Na}^{+}$current at pulse 10 to pulse 1 . The reduction in activity-dependent $\mathrm{Na}^{+}$current was increased when starting from a $V_{h}$ of $-70 \mathrm{mV}$ instead of $\mathrm{V}_{\mathrm{h}}$ of $-90 \mathrm{mV}$. Because $\mathrm{V}_{\mathrm{h}}$ of $-70 \mathrm{mV}$ is closer to the $V_{1 / 2}$ of inactivation, more VGSCs will be inactivated during these protocols than when holding at $\mathrm{V}_{\mathrm{h}}$ of $-90 \mathrm{mV}$. Therefore, the larger reduction in activity-dependent $\mathrm{Na}^{+}$current further confirms isoflurane preferentially inhibits channels in the inactivated state. Increasing the frequency from 50 to $100 \mathrm{~Hz}$ further increased the block by isoflurane, although only a subset of neurons is capable of firing at this rate in vivo, including fast-spiking GABAergic interneurons. Using the same protocol, the activity-dependent inhibition by isoflurane was also observed in rat neurohypophysial nerve terminals. The authors then constructed a three-state Markov model with the data obtained from their electrophysiology experiments. The model provided quantitative support of the hypothesis that the activity-dependent block of isoflurane is achieved via stabilization of the inactivated state (Purtell, 2015; Purtell et al., 2015). The novel 

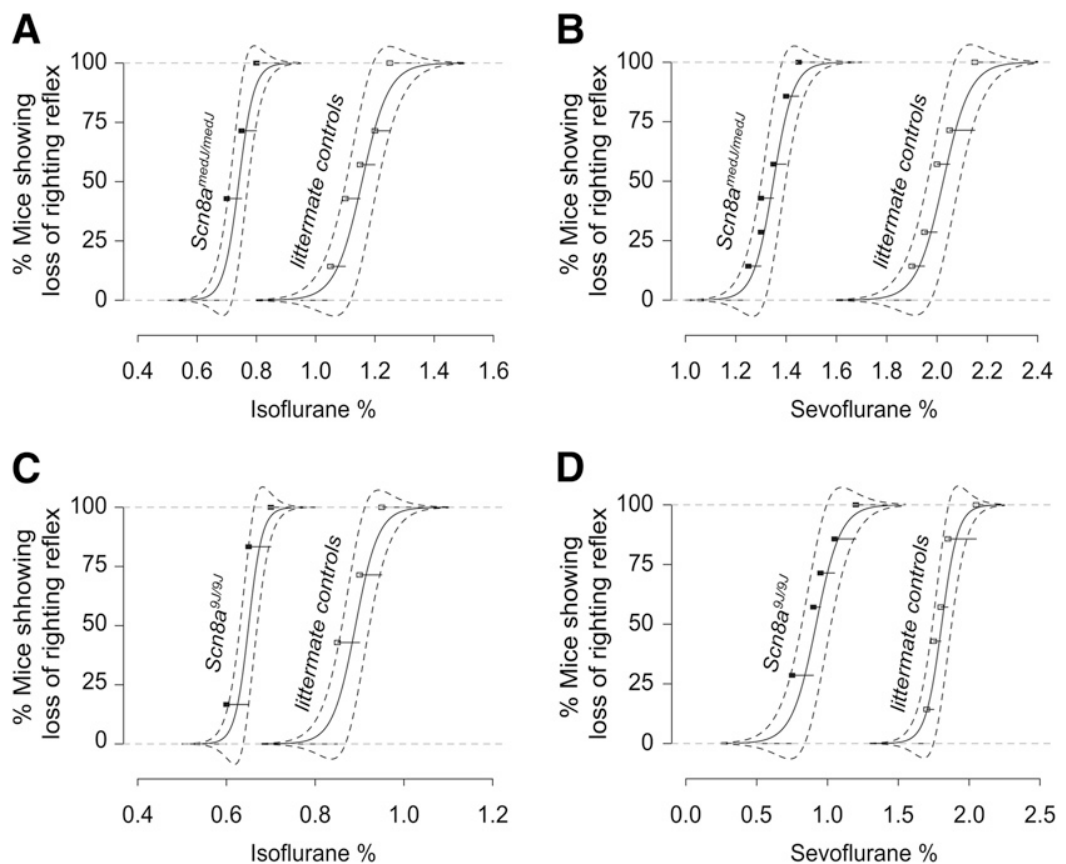

Fig. 7. Increased anesthetic sensitivity in mice with loss-of-function mutations in $S c n 8 a$ (the gene that encodes $\mathrm{Na}_{\mathrm{v}} 1.6$ ). Best-fit dose-response curves along with 95\% confidence band (dashed lines) show the behavioral response (loss of righting reflex) of Scn8a ${ }^{\text {medJ/medJ }}\left(\mathrm{A}\right.$ and $\mathrm{B}$ ) and Scn8 $\mathrm{a}^{9 \mathrm{~J} / 9 \mathrm{~J}}$ (C and D) mice and their respective littermate control groups to increasing concentrations of isoflurane and sevoflurane anesthesia. EC 50 shows a statistically significant leftward shift in the mutant mice, indicating hypersensitivity to anesthesia mediated by $\mathrm{Na}_{\mathrm{v}} 1.6$. Reproduced with permission from Pal et al. (2015).

activity-dependent action of isoflurane on $\mathrm{Na}_{\mathrm{v}} 1.2$ is nonetheless important as it is one of the major VGSC isoforms expressed in the central nervous system. The authors claim the additional $\sim 20 \%$ increase in $\mathrm{Na}^{+}$ current block at $50 \mathrm{~Hz}$ stimulation from $\mathrm{V}_{\mathrm{h}}$ of $-70 \mathrm{mV}$ has major implications for the in vivo systems level mechanism of isoflurane. If isoflurane increasingly blocks VGSCs as neurons fire more frequently, information-rich networks of fast-firing neurons will be differentially suppressed. Recent experiments have provided supporting evidence that isoflurane is a subtype-selective inhibitor of the neuronal VGSCs. In ND7/ 23 cells, clinically relevant concentrations of isoflurane showed a voltage-dependent reduction (between $15 \%$ and $20 \%$ ) of peak $\mathrm{Na}^{+}$current mediated by $\mathrm{Na}_{\mathrm{v}} 1.3$ and $\mathrm{Na}_{\mathrm{v}} 1.6$, but no significant effect was observed in cells expressing $\mathrm{Na}_{\mathrm{v}} 1.1$ (Zhou et al., 2019). Analysis of the activity other halogenated ethers have on the neuronal subtypes $\mathrm{Na}_{\mathrm{v}} 1.1,1.3$, and 1.6 will be important to determine whether this activity-dependent and subtypeselective effect is agent-specific.

\section{Conclusion}

The reduction in peak $\mathrm{Na}^{+}$current by the halogenated ethers in the experiments reviewed was consistently minor, leading to a $\sim 10 \%-20 \%$ decrease in peak current, except for desflurane, which led to a $48 \%$ decrease in peak $\mathrm{Na}^{+}$current at $0.85 \mathrm{mM}$ (Ouyang et al., 2009). However, even small disturbances in $\mathrm{Na}^{+}$channel function, such as disruption of normal inactivation kinetics, can lead to significant changes in the formation, stability, and coherence of neural assemblies in the brain. Minor disruptions in voltage-gated ion channel function are predicted to cascade into more dramatic dysfunction in the oscillatory activity of neural networks (Arhem et al., 2003).

Subtype-specific VGSC inhibition by the halogenated ethers could lead to a heterogenous reduction in action potential conduction velocity. This reduction may corrupt spike-timing precision in a way that is sufficient to disrupt higher-order network-level interactions, while leaving local network functions intact. Higher-order functions that rely on multiple integrated inputs are dependent on precise temporal coordination. Disruption of these higher-order functions likely contributes to the loss of consciousness under general anesthesia. Hentschke et al. (2017) investigated the effects of isoflurane on stimulated and spontaneous activity in mouse thalamocortical slices using a multi-electrode array. In the presence of clinically relevant concentrations of isoflurane ( $>1 \mathrm{MAC}$ ), the authors found a more prominent suppression of polysynaptic signal propagation throughout the cortex than of the monosynaptic signal propagation traveling from the thalamus to the cortex in response to stimuli. The isoflurane-induced suppression had a more significant effect on burst propagation and long-latency signaling as opposed to burst initiation and shorter-latency signaling (Hentschke et al., 2017). Suppression of VGSCs by isoflurane, and the other halogenated ethers, may play a role in the 
anesthetic-induced breakdown of long-range cortical communication and temporal coordination.

If halogenated ethers inhibit presynaptic VGSCs in excitatory neurons, for example, this can lead to depressed glutamate release. Altered neurotransmission via presynaptic sodium channel inhibition represents a potential link between the molecular actions of general anesthetics and the known alterations of brain network function during general anesthesia such as disrupted functional connectivity and increased modularity (Kim et al., 2018; Lee and Mashour, 2018). Importantly, these network-level mechanisms of anesthesia may be relevant across multiple species, including nonmammalian animals and even single-cell organisms (which are reversibly immobilized by general anesthetics). Because the evolution of sodium channels is thought to predate the origin of a nervous system in animals (Liebeskind et al., 2011), VGSC inhibition may provide insight into the known susceptibility to general anesthetics across phyla.

In this study, we have reviewed the mechanisms of action of halogenated ethers on VGSCs almost exclusively. Halogenated ethers, like many anesthetics, are promiscuous drugs known to target multiple proteins (Eckenhoff and Johansson, 1997). It is thus likely that the various therapeutic endpoints of the anesthetized state can be attributed to different protein targets, with some of these endpoints requiring the concerted action of multiple targets. Through understanding the role of VGSCs, we may gain further insight into both the molecular and network-level mechanisms of general anesthesia.

\section{Authorship Contributions}

Wrote or contributed to the writing of the manuscript: Denomme, Hull, Mashour.

\section{References}

Alroy G, Su H, and Yaari Y (1999) Protein kinase C mediates muscarinic block of intrinsic bursting in rat hippocampal neurons. J Physiol 518:71-79.

Arhem P, Klement G, and Nilsson J (2003) Mechanisms of anesthesia: towards integrating network, cellular, and molecular level modeling. Neuropsychopharmacology 28 (Suppl 1):S40-S47.

Artusio JF, Vanpoznak A, Hunt RE, Tiers FM, and Alexander M (1960) A clinical evaluation of methoxyflurane in man. Anesthesiology 21:512-517.

Azouz R, Jensen MS, and Yaari Y (1994) Muscarinic modulation of intrinsic burst firing in rat hippocampal neurons. Eur J Neurosci 6:961-966.

Barber AF, Carnevale V, Klein ML, Eckenhoff RG, and Covarrubias M (2014) Modulation of a voltage-gated $\mathrm{Na}+$ channel by sevoflurane involves multiple sites and distinct mechanisms. Proc Natl Acad Sci USA 111:6726-6731.

Barnes S and Hille B (1988) Veratridine modifies open sodium channels. J Gen Physiol 91:421-443.

Baumgart JP, Zhou ZY, Hara M, Cook DC, Hoppa MB, Ryan TA, and Hemmings HC $\mathrm{Jr}$ (2015) Isoflurane inhibits synaptic vesicle exocytosis through reduced $\mathrm{Ca}^{2+}$ influx, not $\mathrm{Ca}^{2+}$-exocytosis coupling. Proc Natl Acad Sci USA 112:11959-11964.

Bean BP (1979) Modification of Sodium and Potassium Channel Kinetics by Diethyl Ether and Studies on Sodium Channel Inactivation in the Crayfish Giant Axon Membrane. Ph.D. thesis, University of Rochester, Rochester, NY.

Bean BP, Shrager P, and Goldstein DA (1981) Modification of sodium and potassium channel gating kinetics by ether and halothane. J Gen Physiol 77:233-253.

Beneski DA and Catterall WA (1980) Covalent labeling of protein components of the sodium channel with a photoactivable derivative of scorpion toxin. Proc Natl Acad Sci USA 77:639-643.

Berg-Johnsen J and Langmoen IA (1986) Isoflurane effects in rat hippocampal cortex: a quantitative evaluation of different cellular sites of action. Acta Physiol Scand 128:613-618.

Berg-Johnsen J and Langmoen IA (1990) Mechanisms concerned in the direct effect of isoflurane on rat hippocampal and human neocortical neurons. Brain Res 507: 28-34.
Berg-Johnsen J and Langmoen IA (1992) The effect of isoflurane on excitatory synaptic transmission in the rat hippocampus. Acta Anaesthesiol Scand 36:350-355.

Bigelow HJ (1846) Insensibility during surgical operations produced by inhalation The Boston Medical and Surgical Journal 35:309-317.

Booth HS and Bixby EM (1932) Fluorine derivatives of chloroform. J Ind Eng Chem 24:637-641.

Caldwell JH, Schaller KL, Lasher RS, Peles E, and Levinson SR (2000) Sodium channel $\mathrm{Na}(\mathrm{v}) 1.6$ is localized at nodes of ranvier, dendrites, and synapses. Proc Natl Acad Sci USA 97:5616-5620.

Calhoun JD and Isom LL (2014) The role of non-pore-forming $\beta$ subunits in physiology and pathophysiology of voltage-gated sodium channels. Handb Exp Pharmacol 221:51-89.

Calverley RK (1986) Fluorinated anesthetics. II. The early years. Surv Anesthesiol 30:170-172.

Campagna JA, Miller KW, and Forman SA (2003) Mechanisms of Actions of Inhaled Anesthetics. N Engl J Med 348 (21):2110-2124.

Cantrell AR and Catterall WA (2001) Neuromodulation of $\mathrm{Na}^{+}$channels: an unexpected form of cellular plasticity. Nat Rev Neurosci 2:397-407.

Cantrell AR, Ma JY, Scheuer T, and Catterall WA (1996) Muscarinic modulation of sodium current by activation of protein kinase $\mathrm{C}$ in rat hippocampal neurons. Neuron 16:1019-1026.

Cantrell AR, Scheuer T, and Catterall WA (1999) Voltage-dependent neuromodulation of $\mathrm{Na}+$ channels by $\mathrm{D} 1$-like dopamine receptors in rat hippocampal neurons. J Neurosci 19:5301-5310.

Cantrell AR, Smith RD, Goldin AL, Scheuer T, and Catterall WA (1997) Dopaminergic modulation of sodium current in hippocampal neurons via cAMP-dependent phosphorylation of specific sites in the sodium channel alpha subunit. $J$ Neurosci 17:7330-7338.

Carr DB, Day M, Cantrell AR, Held J, Scheuer T, Catterall WA, and Surmeier DJ (2003) Transmitter modulation of slow, activity-dependent alterations in sodium channel availability endows neurons with a novel form of cellular plasticity. Neuron 39:793-806.

Cascorbi HF and Singh-Amaranath AV (1972) Fluroxene Toxicity in Mice. Anesthesiology 37:480-482.

Catterall WA (2001) Physiology: a one-domain voltage-gated sodium channel in bacteria. Science 294:2306-2308.

Catterall WA (2012) Voltage-gated sodium channels at 60: structure, function and pathophysiology. J Physiol 590:2577-2589.

Catterall WA, Goldin AL, and Waxman SG (2005) International Union of Pharmacology. XLVII. Nomenclature and structure-function relationships of voltage-gated sodium channels. Pharmacol Rev 57:397-409.

Charalambous $\mathrm{K}$ and Wallace BA (2011) NaChBac: the long lost sodium channel ancestor. Biochemistry 50:6742-6752.

Chen Y, Yu FH, Sharp EM, Beacham D, Scheuer T, and Catterall WA (2008) Functional properties and differential neuromodulation of $\mathrm{Na}_{\mathrm{v}}{ }_{\mathrm{v}} 1.6$ channels. $\mathrm{Mol}$ Cell Neurosci 38:607-615.

Chen Y, Yu FH, Surmeier DJ, Scheuer T, and Catterall WA (2006) Neuromodulation of $\mathrm{Na}+$ channel slow inactivation via cAMP-dependent protein kinase and protein kinase C. Neuron 49:409-420.

Cordus V (1561) De artificiosis extractionibus liber.

Covarrubias M, Barber AF, Carnevale V, Treptow W, and Eckenhoff RG (2015 Mechanistic insights into the modulation of voltage-gated ion channels by inhalational anesthetics. Biophys J 109:2003-2011.

Crandell WB, Pappas SG, and Macdonald A (1966) Nephrotoxicity associated with methoxyflurane anesthesia. Anesthesiology 27:591-607.

Duch DS, Rehberg B, and Vysotskaya TN (1998) Volatile anesthetics significantly suppress central and peripheral mammalian sodium channels. Toxicol Lett 100-101:255-263.

Eckenhoff RG and Johansson JS (1997) Molecular interactions between inhaled anesthetics and proteins. Pharmacol Rev 49:343-367.

Elliott JR, Elliott AA, Harper AA, and Winpenny JP (1992) Effects of general anaesthetics on neuronal sodium and potassium channels. Gen Pharmacol 23: 1005-1011.

Elliott JR, Haydon DA, and Hendry BM (1984) Anaesthetic action of esters and ketones: evidence for an interaction with the sodium channel protein in squid axons. $J$ Physiol 354:407-418.

Featherstone DE, Richmond JE, and Ruben PC (1996) Interaction between fast and slow inactivation in Skm1 sodium channels. Biophys J 71:3098-3109.

Fenster J (2001) Ether Day, Harper Collins, New York.

Fleidervish IA, Friedman A, and Gutnick MJ (1996) Slow inactivation of $\mathrm{Na}^{+}$current and slow cumulative spike adaptation in mouse and guinea-pig neocortical neurones in slices [published correction appears in J Physiol (Lond) (1996) 494:907]. J Physiol 493:83-97.

Forman SA and Chin VA (2008) General anesthetics and molecular mechanisms of unconsciousness. Int Anesthesiol Clin 46:43-53.

Frank GB and Pinsky C (1966) Tetrodotoxin-induced central nervous system depression. Br J Pharmacol Chemother 26:435-443.

Frank GB and Sanders HD (1963) A proposed common mechanism of action for general and local anesthetics in the central nervous system. $\mathrm{Br} J$ Pharmacol Chemother 21:1-9.

Franks NP (2006) Molecular targets underlying general anaesthesia. Br J Pharmacol 147 (Suppl 1):S72-S81.

Franks NP (2008) General anaesthesia: from molecular targets to neuronal pathways of sleep and arousal. Nat Rev Neurosci 9:370-386.

Franks NP and Lieb WR (1978) Where do general anaesthetics act? Nature 274: 339-342.

Franks NP and Lieb WR (1979) The structure of lipid bilayers and the effects of general anaesthetics: an x-ray and neutron diffraction study. J Mol Biol 133:469-500.

Franks NP and Lieb WR (1981) Is membrane expansion relevant to anaesthesia? Nature 292:248-251. 
Franks NP and Lieb WR (1982) Molecular mechanisms of general anaesthesia. $\mathrm{Na}$ ture 300:487-493.

Franks NP and Lieb WR (1984) Do general anaesthetics act by competitive binding to specific receptors? Nature 310:599-601.

Franks NP and Lieb WR (1993) Selective actions of volatile general anaesthetics at molecular and cellular levels. Br J Anaesth 71:65-76.

Franks NP and Lieb WR (1994) Molecular and cellular mechanisms of general anaesthesia. Nature 367:607-614.

Franks NP and Lieb WR (1996) Temperature dependence of the potency of volatile general anesthetics: implications for in vitro experiments. Anesthesiology 84: $716-720$.

Goldin AL (2001) Resurgence of sodium channel research. Annu Rev Physiol 63: 871-894.

Goldin AL, Snutch T, Lübbert H, Dowsett A, Marshall J, Auld V, Downey W, Fritz LC, Lester HA, Dunn R, et al. (1986) Messenger RNA coding for only the alpha subunit of the rat brain $\mathrm{Na}$ channel is sufficient for expression of functional channels in Xenopus oocytes. Proc Natl Acad Sci USA 83:7503-7507.

Gong B, Rhodes KJ, Bekele-Arcuri Z, and Trimmer JS (1999) Type I and type II $\mathrm{Na}(+)$ channel alpha-subunit polypeptides exhibit distinct spatial and temporal patterning, and association with auxiliary subunits in rat brain. J Comp Neurol 412:342-352.

Harris RA and Bruno P (1985) Effects of ethanol and other intoxicant-anesthetics on voltage-dependent sodium channels of brain synaptosomes. J Pharmacol Exp Ther 232:401-406.

Haydon DA and Urban BW (1983) The effects of some inhalation anaesthetics on the sodium current of the squid giant axon. J Physiol 341:429-439.

Haydon DA and Urban BW (1986) The actions of some general anaesthetics on the potassium current of the squid giant axon. J Physiol 373:311-327.

Heinbecker P and Bartley SH (1940) Action of ether and nembutal on the nervous system. J Neurophysiol 3:219-236.

Heinemann SH, Terlau H, Stühmer W, Imoto K, and Numa S (1992) Calcium channel characteristics conferred on the sodium channel by single mutations. Nature $\mathbf{3 5 6}$ 441-443.

Hemmings HC Jr (2009) Sodium channels and the synaptic mechanisms of inhaled anaesthetics. Br J Anaesth 103:61-69.

Hemmings HC Jr, Akabas MH, Goldstein PA, Trudell JR, Orser BA, and Harrison NL (2005a) Emerging molecular mechanisms of general anesthetic action. Trends Pharmacol Sci 26:503-510.

Hemmings HC Jr, Yan W, Westphalen RI, and Ryan TA (2005b) The general anesthetic isoflurane depresses synaptic vesicle exocytosis. Mol Pharmacol 67: 1591-1599.

Hentschke H, Raz A, Krause BM, Murphy CA, and Banks MI (2017) Disruption of cortical network activity by the general anaesthetic isoflurane. $\mathrm{Br} J$ Anaesth $\mathbf{1 1 9}$ $685-696$.

Herold KF, Andersen OS, and Hemmings HC Jr (2017a) Divergent effects of anesthetics on lipid bilayer properties and sodium channel function. Eur Biophys J 46: $617-626$.

Herold KF and Hemmings HC Jr (2012) Sodium channels as targets for volatile anesthetics. Front Pharmacol 3:50.

Herold KF, Nau C, Ouyang W, and Hemmings HC Jr (2009) Isoflurane inhibits the tetrodotoxin-resistant voltage-gated sodium channel $\mathrm{Na}_{\mathrm{v}}$ 1.8. Anesthesiology 111: 591-599.

Herold KF, Sanford RL, Lee W, Andersen OS, and Hemmings HC Jr (2017b) Clinical concentrations of chemically diverse general anesthetics minimally affect lipid bilayer properties. Proc Natl Acad Sci USA 114:3109-3114.

Herold KF, Sanford RL, Lee W, Schultz MF, Ingólfsson HI, Andersen OS, and Hemmings HC Jr (2014) Volatile anesthetics inhibit sodium channels without altering bulk lipid bilayer properties. J Gen Physiol 144:545-560.

Hille B (2001) Ion Channels of Excitable Membranes, 3rd ed., Sinauer Associates, Sunderland, MA.

Hodgkin AL and Huxley AF (1952) A quantitative description of membrane current and its application to conduction and excitation in nerve. J Physiol 117:500-544.

Hodgkin AL and Katz B (1949) The effect of sodium ions on the electrical activity of giant axon of the squid. $J$ Physiol 108:37-77.

Horishita T, Eger EI II, and Harris RA (2008) The effects of volatile aromatic anesthetics on voltage-gated $\mathrm{Na}+$ channels expressed in Xenopus oocytes. Anesth Analg 107:1579-1586.

Hu W, Tian C, Li T, Yang M, Hou H, and Shu Y (2009) Distinct contributions of $\mathrm{Na}_{(\mathrm{v})} 1.6$ and $\mathrm{Na}_{(\mathrm{v})} 1.2$ in action potential initiation and backpropagation. Nat Neurosci 12:996-1002.

Hull JM and Isom LL (2018) Voltage-gated sodium channel $\beta$ subunits: the power outside the pore in brain development and disease. Neuropharmacology 132:43-57.

Inoue F and Frank GB (1962) Action of procaine on frog skeletal muscle. J Pharmacol Exp Ther 136:190-196.

Inoue F and Frank GB (1965) Action of ether on frog skeletal muscle. Can J Physiol Pharmacol 43:751-761.

Johnson KW, Herold KF, Milner TA, Hemmings HC Jr, and Platholi J (2017) Sodium channel subtypes are differentially localized to pre- and post-synaptic sites in rat hippocampus. J Comp Neurol 525:3563-3578.

Jung HY, Mickus T, and Spruston N (1997) Prolonged sodium channel inactivation contributes to dendritic action potential attenuation in hippocampal pyramida neurons. J Neurosci 17:6639-6646.

Kalume F, Oakley JC, Westenbroek RE, Gile J, de la Iglesia HO, Scheuer T, and Catterall WA (2015) Sleep impairment and reduced interneuron excitability in a mouse model of Dravet Syndrome. Neurobiol Dis 77:141-154.

Kendig JJ, Courtney KR, and Cohen EN (1979) Anesthetics: molecular correlates of voltage- and frequency-dependent sodium channel block in nerve. J Pharmacol Exp Ther 210:446-452.

Kim H, Hudetz AG, Lee J, Mashour GA, and Lee U; ReCCognition Study Group (2018) Estimating the integrated information measure phi from high-density electroencephalography during states of consciousness in humans. Front Hum Neurosci 12:42.

Kinde MN, Bondarenko V, Granata D, Bu W, Grasty KC, Loll PJ, Carnevale V, Klein ML, Eckenhoff RG, Tang P, et al. (2016) Fluorine-19 NMR and computational quantification of isoflurane binding to the voltage-gated sodium channel $\mathrm{NaChBac}$. Proc Natl Acad Sci USA 113:13762-13767.

Krantz JC, Carr CJ, Lu G, and Bell FK (1953) Anesthesia. XL. The anesthetic action of trifluoroethyl vinyl ether. J Pharmacol Exp Ther 108:488-495.

Krzemien DM, Schaller KL, Levinson SR, and Caldwell JH (2000) Immunolocalization of sodium channel isoform $\mathrm{NaCh} 6$ in the nervous system. J Comp Neurol 420: $70-83$.

Lavelle E and Kurra S (2017) Pharmacology of Inhaled Anesthetics, Basic Sciences in Anesthesia pp 177-193, Springer International Publishing, Switzerland.

Lee U and Mashour GA (2018) Role of network science in the study of anesthetic state transitions. Anesthesiology 129:1029-1044.

Li M, West JW, Numann R, Murphy BJ, Scheuer T, and Catterall WA (1993) Convergent regulation of sodium channels by protein kinase $\mathrm{C}$ and cAMP-dependent protein kinase. Science 261:1439-1442.

Li T, Tian C, Scalmani P, Frassoni C, Mantegazza M, Wang Y, Yang M, Wu S, and Shu Y (2014) Action potential initiation in neocortical inhibitory interneurons. PLoS Biol 12:e1001944.

Liebeskind BJ, Hillis DM, and Zakon HH (2011) Evolution of sodium channels predates the origin of nervous systems in animals. Proc Natl Acad Sci USA 108: 9154-9159.

Lingamaneni R, Birch ML, and Hemmings HC Jr (2001) Widespread inhibition of sodium channel-dependent glutamate release from isolated nerve terminals by isoflurane and propofol [published correction appears in Anesthesiology (2002) 96: 782]. Anesthesiology 95:1460-1466.

Lingamaneni R and Hemmings HC Jr (2003) Differential interaction of anaesthetics and antiepileptic drugs with neuronal $\mathrm{Na}+$ channels, $\mathrm{Ca} 2+$ channels, and GABA(A) receptors. Br J Anaesth 90:199-211.

Lipkind GM and Fozzard HA (2008) Voltage-gated Na channel selectivity: the role of the conserved domain III lysine residue. J Gen Physiol 131:523-529.

Long CW (1849) An account of the first use of sulphuric ether by inhalation as an anaesthetic in surgical operations. South Med Surg J 5:705-713.

Lorincz A and Nusser Z (2010) Molecular identity of dendritic voltage-gated sodium channels. Science 328:906-909.

Maclver MB, Mikulec AA, Amagasu SM, and Monroe FA (1996) Volatile anesthetics depress glutamate transmission via presynaptic actions. Anesthesiology 85: $823-834$

Makinson CD, Tanaka BS, Sorokin JM, Wong JC, Christian CA, Goldin AL, Escayg A, and Huguenard JR (2017) Regulation of thalamic and cortical network synchrony by Scn8a. Neuron $\mathbf{9 3} \cdot 1165-1179$ e6.

Mashour GA, Forman SA, and Campagna JA (2005) Mechanisms of general anesthesia: from molecules to mind. Best Pract Res Clin Anaesthesiol 19: 349-364.

Maurice N, Tkatch T, Meisler M, Sprunger LK, and Surmeier DJ (2001) D1/D5 dopamine receptor activation differentially modulates rapidly inactivating and persistent sodium currents in prefrontal cortex pyramidal neurons. J Neurosci 21: $2268-2277$.

McCusker EC, Bagnéris C, Naylor CE, Cole AR, D'Avanzo N, Nichols CG, and Wallace BA (2012) Structure of a bacterial voltage-gated sodium channel pore reveals mechanisms of opening and closing. Nat Commun 3:1102.

Metherate R, Cox CL, and Ashe JH (1992) Cellular bases of neocortical activation modulation of neural oscillations by the nucleus basalis and endogenous acetylcholine. J Neurosci 12:4701-4711.

Meyer H (1899) Zur theorie der alkoholnarkose. Arch Exp Pathol Pharmakol 42: $109-118$

Miller R, Eriksson L, Fleisher L, Wiener-Kronish J, Cohen N, and Young W (2015) Miller's Anesthesia, Saunders, Philadelphia, PA.

Mitrovic N, George AL Jr, and Horn R (2000) Role of domain 4 in sodium channel slow inactivation. J Gen Physiol 115:707-718.

Morris L (1972) Fluroxene, Modern Inhalation Anesthetics 30, pp 93-102, Springer, Berlin.

Ogiwara I, Miyamoto H, Morita N, Atapour N, Mazaki E, Inoue I, Takeuchi T, Itohara S, Yanagawa $\mathrm{Y}$, Obata $\mathrm{K}$, et al. (2007) $\mathrm{Na}_{\mathrm{v}} 1.1$ localizes to axons of parvalbumin-positive inhibitory interneurons: a circuit basis for epileptic seizures in mice carrying an Scn1a gene mutation. J Neurosci 27:5903-5914.

Okaty BW, Miller MN, Sugino K, Hempel CM, and Nelson SB (2009) Transcriptional and electrophysiological maturation of neocortical fast-spiking GABAergic interneurons. J Neurosci 29:7040-7052.

O'Malley HA and Isom LL (2015) Sodium channel $\beta$ subunits: emerging targets in channelopathies. Annu Rev Physiol 77:481-504.

Ong BH, Tomaselli GF, and Balser JR (2000) A structural rearrangement in the sodium channel pore linked to slow inactivation and use dependence. J Gen Physiol 116:653-662.

Ouyang W and Hemmings HC Jr (2005) Depression by isoflurane of the action potential and underlying voltage-gated ion currents in isolated rat neurohypophysia nerve terminals. J Pharmacol Exp Ther 312:801-808.

Ouyang W and Hemmings HC Jr (2007) Isoform-selective effects of isoflurane on voltage-gated $\mathrm{Na}+$ channels. Anesthesiology 107:91-98.

Ouyang W, Herold KF, and Hemmings HC Jr (2009) Comparative effects of halogenated inhaled anesthetics on voltage-gated $\mathrm{Na}+$ channel function. Anesthesiology 110:582-590.

Ouyang W, Jih TY, Zhang TT, Correa AM, and Hemmings HC Jr (2007) Isoflurane inhibits $\mathrm{NaChBac}$, a prokaryotic voltage-gated sodium channel. J Pharmacol Exp Ther 322:1076-1083.

Ouyang W, Wang G, and Hemmings HC Jr (2003) Isoflurane and propofol inhibit voltage-gated sodium channels in isolated rat neurohypophysial nerve terminals. Mol Pharmacol 64:373-381. 
Overton E (1901) Studien über die Narkose zugleich ein Beitrag zur allgemeinen Pharmakologie, Verlag von Gustav Fischer, Jena, Germany.

Pal D, Jones JM, Wisidagamage S, Meisler MH, and Mashour GA (2015) Reduced $\mathrm{Na}_{\mathrm{v}} 1.6$ sodium channel activity in mice increases in vivo sensitivity to volatile anesthetics. PLoS One 10:e134960.

Pan X, Li Z, Zhou Q, Shen H, Wu K, Huang X, Chen J, Zhang J, Zhu X, Lei J, et al (2018) Structure of the human voltage-gated sodium channel $\mathrm{Na}_{\mathrm{v}} 1.4$ in complex with $\beta 1$. Science 362:eaau2486.

Payandeh J, Scheuer T, Zheng N, and Catterall WA (2011) The crystal structure of a voltage-gated sodium channel. Nature 475:353-358.

Purtell K (2015) Effects of the General Anesthetic Isoflurane on Voltage-Gated Sodium Channels and the Pre-synaptic Action Potential. Ph.D. thesis, Cornell University, Ithaca, NY.

Purtell K, Gingrich KJ, Ouyang W, Herold KF, and Hemmings HC Jr (2015) Activitydependent depression of neuronal sodium channels by the general anaesthetic isoflurane. Br J Anaesth 115:112-121.

Raju SG, Barber AF, LeBard DN, Klein ML, and Carnevale V (2013) Exploring volatile general anesthetic binding to a closed membrane-bound bacterial voltagegated sodium channel via computation. PLOS Comput Biol 9:e1003090.

Ratnakumari L, Vysotskaya TN, Duch DS, and Hemmings HC Jr (2000) Differential effects of anesthetic and nonanesthetic cyclobutanes on neuronal voltage-gated sodium channels. Anesthesiology 92:529-541.

Rehberg B, Xiao YH, and Duch DS (1996) Central nervous system sodium channels are significantly suppressed at clinical concentrations of volatile anesthetics. Anesthesiology 84:1223-1233, discussion 27A

Richards CD, Russell WJ, and Smaje JC (1975) The action of ether and methoxyflurane on synaptic transmission in isolated preparations of the mammalian cortex. J Physiol 248:121-142.

Richards CD and White AE (1975) The actions of volatile anaesthetics on synaptic transmission in the dentate gyrus. J Physiol 252:241-257.

Robbins BH (1946) Preliminary studies of the anesthetic activity of fluorinated hydrocarbons. J Pharmacol Exp Ther 86:197-204.

Rudolph U and Antkowiak B (2004) Molecular and neuronal substrates for general anaesthetics. Nat Rev Neurosci 5:709-720.

Rudy B (1978) Slow inactivation of the sodium conductance in squid giant axons: pronase resistance. J Physiol 283:1-21.

Sand RM, Gingrich KJ, Macharadze T, Herold KF, and Hemmings HC Jr (2017) Isoflurane modulates activation and inactivation gating of the prokaryotic $\mathrm{Na}^{+}$ channel NaChBac. J Gen Physiol 149:623-638.

Schauf CL, Pencek TL, and Davis FA (1976) Slow sodium inactivation in Myxicola axons: evidence for a second inactive state. Biophys $J$ 16:771-778.

Scheuer T (2011) Regulation of sodium channel activity by phosphorylation. Semin Cell Dev Biol 22:160-165.

Schlame M and Hemmings HC Jr (1995) Inhibition by volatile anesthetics of endogenous glutamate release from synaptosomes by a presynaptic mechanism. Anesthesiology 82:1406-1416.

Seeman P (1972) The membrane actions of anesthetics and tranquilizers. Pharmacol Rev 24:583-655.

Seeman P (1974) The actions of nervous system drugs on cell membranes. Hosp Pract 9:93-101.

Shiraishi M and Harris RA (2004) Effects of alcohols and anesthetics on recombinant voltage-gated Na+ channels. J Pharmacol Exp Ther 309:987-994.

Stadnicka A, Kwok WM, Hartmann HA, and Bosnjak ZJ (1999) Effects of halothane and isoflurane on fast and slow inactivation of human heart hH1a sodium channels. Anesthesiology 90:1671-1683.

Tempelhoff R (1997) The new inhalational anesthetics desflurane and sevoflurane are valuable additions to the practice of neuroanesthesia: con. J Neurosurg Anes thesiol 9:69-71.

Terrell RC (2008) The invention and development of enflurane, isoflurane, sevoflurane, and desflurane. Anesthesiology 108:531-533.

Thesleff S (1956) The effect of anesthetic agents on skeletal muscle membrane. Acta Physiol Scand 37:335-349.

Todt H, Dudley SC Jr, Kyle JW, French RJ, and Fozzard HA (1999) Ultra-slow inactivation in mu1 $\mathrm{Na}^{+}$channels is produced by a structural rearrangement of the outer vestibule. Biophys J 76:1335-1345.

Urban BW and Haydon DA (1987) The actions of halogenated ethers on the ionic currents of the squid giant axon. Proc $R$ Soc Lond B Biol Sci 231:13-26.

Van Wart A, Trimmer JS, and Matthews G (2007) Polarized distribution of ion channels within microdomains of the axon initial segment. J Comp Neurol $\mathbf{5 0 0}$ $339-352$.
Vedantham V and Cannon SC (1998) Slow inactivation does not affect movement of the fast inactivation gate in voltage-gated $\mathrm{Na}+$ channels. J Gen Physiol 111: 83-93.

Wang Y, Yang E, Wells MM, Bondarenko V, Woll K, Carnevale V, Granata D, Klein ML, Eckenhoff RG, Dailey WP, et al. (2018) Propofol inhibits the voltagegated sodium channel $\mathrm{NaChBac}$ at multiple sites. J Gen Physiol 150: 1317-1331.

Weiser TG, Haynes AB, Molina G, Lipsitz SR, Esquivel MM, Uribe-Leitz T, Fu R, Azad T, Chao TE, Berry WR, et al. (2015) Estimate of the global volume of surgery in 2012: an assessment supporting improved health outcomes. Lancet 385 (Suppl 2):S11.

Westenbroek RE, Merrick DK, and Catterall WA (1989) Differential subcellular localization of the RI and RII $\mathrm{Na}^{+}$channel subtypes in central neurons. Neuron 3 : 695-704.

Westphalen RI and Hemmings HC Jr (2003) Selective depression by general anesthetics of glutamate versus GABA release from isolated cortical nerve terminals. J Pharmacol Exp Ther 304:1188-1196.

Westphalen RI and Hemmings HC Jr (2006a) Volatile anesthetic effects on glutamate versus GABA release from isolated rat cortical nerve terminals: 4-aminopyridine-evoked release. J Pharmacol Exp Ther 316:216-223.

Westphalen RI and Hemmings HC Jr (2006b) Volatile anesthetic effects on glutamate versus GABA release from isolated rat cortical nerve terminals: basal release. J Pharmacol Exp Ther 316:208-215.

Westphalen RI, Kwak NB, Daniels K, and Hemmings HC Jr (2011) Regional differences in the effects of isoflurane on neurotransmitter release. Neuropharmacology 61:699-706.

Westphalen RI, Yu J, Krivitski M, Jih TY, and Hemmings HC Jr (2010) Regional differences in nerve terminal $\mathrm{Na}^{+}$channel subtype expression and $\mathrm{Na}+$ channeldependent glutamate and GABA release in rat CNS. J Neurochem 113:1611-1620.

Whalen FX, Bacon DR, and Smith HM (2005) Inhaled anesthetics: an historical overview. Best Pract Res Clin Anaesthesiol 19:323-330.

Wu XS, Sun JY, Evers AS, Crowder M, and Wu LG (2004) Isoflurane inhibits transmitter release and the presynaptic action potential. Anesthesiology 100: $663-670$.

Xing Y, Zhang Y, Stabernack CR, Eger EI II, and Gray AT (2003) The use of the potassium channel activator riluzole to test whether potassium channels mediate the capacity of isoflurane to produce immobility. Anesth Analg 97:1020-1024.

Yamaguchi T (1961) Electrophysiological studies on the mechanism of effects of anaesthetics on the isolated frog muscle fibre. J Fac Sci 14:522-535.

Yang E, Granata D, Eckenhoff RG, Carnevale V, and Covarrubias M (2018) Propofol inhibits prokaryotic voltage-gated $\mathrm{Na}^{+}$channels by promoting activation-coupled inactivation. J Gen Physiol 150:1299-1316.

Yin L, Rasch MJ, He Q, Wu S, Dou F, and Shu Y (2017) Selective modulation of axonal sodium channel subtypes by 5 -HT1A receptor in cortical pyramidal neuron. Cereb Cortex 27:509-521.

Yokoyama T, Minami K, Sudo Y, Horishita T, Ogata J, Yanagita T, and Uezono Y (2011) Effects of sevoflurane on voltage-gated sodium channel $\mathrm{Na}_{(\mathrm{v})} 1.8, \mathrm{Na}_{(\mathrm{v})} 1.7$ and $\mathrm{Na}_{(\mathrm{v})} 1.4$ expressed in Xenopus oocytes. J Anesth 25:609-613.

Young CJ and Apfelbaum JL (1995) Inhalational anesthetics: desflurane and sevoflurane. J Clin Anesth 7:564-577.

Yu FH and Catterall WA (2003) Overview of the voltage-gated sodium channel family. Genome Biol 4:207.

Zhang X, Ren W, DeCaen P, Yan C, Tao X, Tang L, Wang J, Hasegawa K, Kumasaka $\mathrm{T}$, He J, et al. (2012) Crystal structure of an orthologue of the NaChBac voltagegated sodium channel. Nature 486:130-134.

Zhang Y, Guzinski M, Eger EI II, Laster MJ, Sharma M, Harris RA, and Hemmings HC Jr (2010) Bidirectional modulation of isoflurane potency by intrathecal tetrodotoxin and veratridine in rats. Br J Pharmacol 159:872-878.

Zhang Y, Laster MJ, Eger EI II, Sharma M, and Sonner JM (2007) Lidocaine, MK 801, and MAC. Anesth Analg 104:1098-1102.

Zhang Y, Sharma M, Eger EI II, Laster MJ, Hemmings HC Jr, and Harris RA (2008) Intrathecal veratridine administration increases minimum alveolar concentration in rats. Anesth Analg 107:875-878.

Zhao W, Zhang M, Liu J, Liang P, Wang R, Hemmings HC, and Zhou C (2019) Isoflurane modulates hippocampal cornu ammonis pyramidal neuron excitability by inhibition of both transient and persistent sodium currents in mice. Anesthe siology DOI: 10.1097/ALN.0000000000002753 [published ahead of print].

Zhou C, Johnson KW, Herold KF, and Hemmings HC Jr (2019) Differential inhibition of neuronal sodium channel subtypes by the general anesthetic isoflurane. J Pharmacol Exp Ther 369:200-211. 